\title{
DISENTANGLING FOOD WEBS INTERACTIONS IN THE LITTORAL OF TEMPERATE SHALLOW LAKES
}

\section{Maria Š́oljar ${ }^{1}$, Jasna Lajtner ${ }^{1}$, Tvrtko Dražina ${ }^{1}$, Reza Malekzadeh- ViayeH ${ }^{2}$, INES RAdanović ${ }^{1}$, IVANa ZrinščaK ${ }^{1}$, Jelena Fressl ${ }^{3}$ \& Dora MatiJašec ${ }^{4}$}

\author{
${ }^{1}$ Department of Biology, Division of Zoology, Faculty of Science, University of Zagreb, \\ Rooseveltov trg 6, HR-10000 Zagreb, Croatia \\ ${ }^{2}$ Artemia and Aquatic Research Institute, Urmia University, Urmia, Iran \\ ${ }^{3}$ Dvokut-Ecro, Ltd, Trnjanska 37, HR-10000 Zagreb, Croatia
}

${ }^{4}$ Department of General and Inorganic Chemistry, Faculty of Chemical Engineering and Technology, University of Zagreb, Marulićev trg 20, HR-10000 Zagreb, Croatia

Špoljar, M., Lajtner, J., Dražina, T., Malekzadeh-Viayeh, R., Radanović, I., Zrinščak, I., Fressl, J. \& Matijašec, D.: Disentangling food webs interactions in the littoral of temperate shallow lakes. Nat. Croat., Vol. 26, No. 2., 145-166, Zagreb, 2017.

Elucidation of food web interactions provides a better understanding of ecosystem functioning, indicates anthropogenic impacts which often cause alterations in environmental conditions and deterioration in feeding networks in terrestrial and aquatic ecosystems. The importance of microfauna and macroinvertebrates in the littoral zones of shallow waters has been poorly studied regarding their trophic interactions. This study compares invertebrate assemblage and food web interactions among epiphyton, zooplankton and benthic macroinvertebrates across structural heterogeneity in the littoral zone of three temperate shallow water bodies. Submerged and structurally-complex stands of Ceratophyllum demersum inhabited a higher abundance of cladocerans and supported a higher diversity and biomass of epiphytic protozoans and invertebrates than floating-leaved Nuphar lutea stands. Analysis of the ecosystem functioning illustrated the increased biomass of macroinvertebrate predators and a preference of predation over planktonic crustaceans in more complex macrophyte stands. Food webs displayed higher complexity and size with habitat heterogeneity, while epiphyton and zooplankton shared an important fraction in food resources among the invertebrate trophic network. Results of food web modelling indicated zooplankton and epiphyton as more vulnerable to invertebrate predation in the complex submerged macrophytes than in the floating-leaved macrophyte stands. Integrated approaches to community, ecosystem and food webs in explanation of complex trophic interactions in the littoral zones confirmed an increase in diversity and food-web functional complexity with structural heterogeneity of microhabitats.

Key words: epiphyton, zooplankton, macroinvertebrates, tactile predators, macrophytes, relaxed niche food web model

Špoljar, M., Lajtner, J., Dražina, T., Malekzadeh-Viayeh, R., Radanović, I., Zrinščak, I., Fressl, J. \& Matijašec, D.: "Raspetljavanje" hranidbenih mreža u litoralu plitkih jezera umjerene zone. Nat. Croat., Vol. 26, No. 2., 145-166, Zagreb, 2017.

Razjašnjenje interakcija u hranidbenoj mreži omogućuje bolje razumijevanje funkcioniranja ekosustava te indikaciju antropogenih učinaka koji često uzrokuju promjene uvjeta okoliša i narušavanje hranidbene mreže kopnenih i vodenih ekosustava. Trofičke interakcije mikrofaune i makrozoobentosa slabo su proučavane u priobalnim (litoralnim) zonama plitkih vodenih tijela. Cilj ovog rada je usporediti interakcije beskralježnjaka i izvora hrane, uključujući epifiton, zooplankton i makrozoobentos u strukturno heterogenim litoralnim zonama triju plikih jezera umjerenog pojasa. U submerznim i strukturno složenim makrofitskim sastojinama vrste Ceratophyllum demersum 
rašljoticalci su razvili populacije velike brojnosti, a također je u njima zbilježena veća raznolikost i biomasa epifitskih protozoa i beskralježnjaka u usporedbi sa sastojinama plutajuće vrste Nuphar lutea. Analiza funkcioniranja ekosustava ukazivala je na to da je u heterogenim makrofitskim sastojinama povećana biomasa makrozoobentoskih predatora i izraženija je njihova predacija nad planktonskim rakovima. Hranidbene mreže bile su složenije u heterogenima staništima, a epifiton i zooplankton imali su važan udio u hranidbenim resursima unutar hranidbene mreže beskralježnjaka. Modeliranje hranidbenih mreža inidicira veću ranjivost zooplanktona i epifitona na predaciju beskralježnjaka u kompleksnijim, submerznim, makrofitskim sastojinama u odnosu na sastojine plutajućih makrofita. Integrirani pristup s aspekta ekologije biocenoza, ekosustava i hranidbenih mreža u objašnjenju složenih trofičkih interakcija u litoralnoj zoni potvrđuje povećanje raznolikosti i kompleksnosti hranidbenih mreža sa strukturalnom heterogenošću mikrostaništa.

Ključne riječi: epifiton, zooplankton, makrozoobentos, taktilni predatori, makrofiti, model hranidbenih mreža

\section{INTRODUCTION}

Littoral zones significantly determine environmental conditions and biotic interactions in shallow water bodies and may consist of a wide range of microhabitats, e.g. various macrophyte stands, harboring diverse faunal and floral entities (Meerhoff et al., 2003; Celewicz-Gołdyn \& KuczyŃsKAKIPPEN, 2017). Macrophytes are key organisms in modifying physico-chemical conditions (metabolic gasses, nutrients and light attenuation) and biotic interactions, e.g., predation and zooplankton migration (SCheffer et al., 1993; KucZyŃSKa-Kippen \& WiśniewsKa, 2011; MeKsuwan et al., 2014). They support various life styles, functional groups and food sources from organic matter, algae and epiphyton (KuczyńsKa-Kippen \& NAgengast, 2006) to littoral microfauna (DugGan et al., 2001; MALEKZADEH-VIAYEH \& ŠPOLJAR, 2012), meiofauna (Ali et al., 2007) and macroinvertebrates (HabdijA et al., 1995; Warfe \& BArmuta, 2006; Kovačević et al., 2007; Cremona et al., 2008). The architectural complexity, age, size and density of macrophytes determine different environmental conditions and their efficiency in providing shelter for zooplankton and fish fry (CAтTANeo et al., 1998; Bogut et al., 2007; BRothers et al., 2013) against fish, as visual, (EstLANDER et al., 2009) and macroinvertebrates as tactile (Gonzalez Sagrario et al., 2009), predators.

Study on aquatic food webs may reflect ecosystem equilibria or deterioration. Food-web ecology integrates community and ecosystem ecology, species interactions and ecosystem functioning (Thompson et al., 2012). Survey of food web connectance and linkage could predict their resilience and robustness due to species extinction or colonisation (Dunne et al., 2002; Thompson et al., 2012). The productivity of water bodies has been known to be an important constituent of feeding preference and positively influences the vertical extension of food-web structures (FrancE, 2012). More recent studies have shown that low productivity supports omnivory and shortens the vertical foodweb structure (THомpson et al., 2012). Spatial organisation of the food web within an ecosystem, e.g. the pelagial - littoral of lakes, can significantly influence trophic relationships and result in functionally different food webs (Сомрте et al., 2016).

Studies on food webs in standing or running freshwaters have been more engaged with trophic interactions related to fish and macroinvertebrates (WARren, 1989; WoodWARd \& Hildrew, 2001; Dézerald et al., 2013; Schriever \& Williams, 2013) than with microfauna (Martinez, 1991; SchmidArAYA et al., 2002a). Here we attempt to assess the impact of macroinvertebrate tactile predators and food resources (algae and epiphyton) in the littoral zones on the microfauna assemblages (sensu lato microscopic heterotrophic organisms: protozoans, rotifers, gastrotrichs, nematodes, ostracods, cladocerans and copepods), presented in zooplankton and epiphyton. Accordingly, the main objectives of this study were: (i) to identify epiphyton, zooplankton and macroinvertebrate assemblages and (ii) to analyse food web properties in the littoral zones of three temperate water bodies. We have focused on the differences in feeding interactions among the structurally different littoral zones as well as on the importance of microscopic epiphytic and planktonic organisms in macroinvertebrates feeding, organic matter cycling and trophic network. 


\section{MATERIALS AND METHODS}

\section{Study area}

This study was conducted in North West Croatia in the vicinity of the city of Zagreb, in the littoral zones of three shallow water bodies of the Sutla backwater (S), Skrcev kut oxbow (Sk, Škrčev kut in Croatian) and Zajarki gravel pit (Z) differing in origin, morphology, anthropogenic impacts, transparency and macrophyte composition and coverage (Fig. 1, Tab. 1a). Sutla backwater is a natural water body, connected with the Sutla River and divided into two interconnected basins: a) the upper basin (UB) with a high coverage of submerged macrophytes, dominated by hornwort, Ceratophyllum demersum, and b) the lower basin (LB) without macrophyte stands, which is not considered in this study. Skrcev kut oxbow was moderately covered by yellow waterlily, Nuphar lutea; this water body was created during highway construction when a Krapina River meander was cut off 50 years ago. Zajarki gravel pit was built on alluvial deposits next to the inflow of the Krapina into the Sava River. Gravel excavation started in the year 1970 and lasted until 2010. The initial small basins created by digging were later joined to form the recent Zajarki gravel pit which is covered with sparse patches of N. lutea.

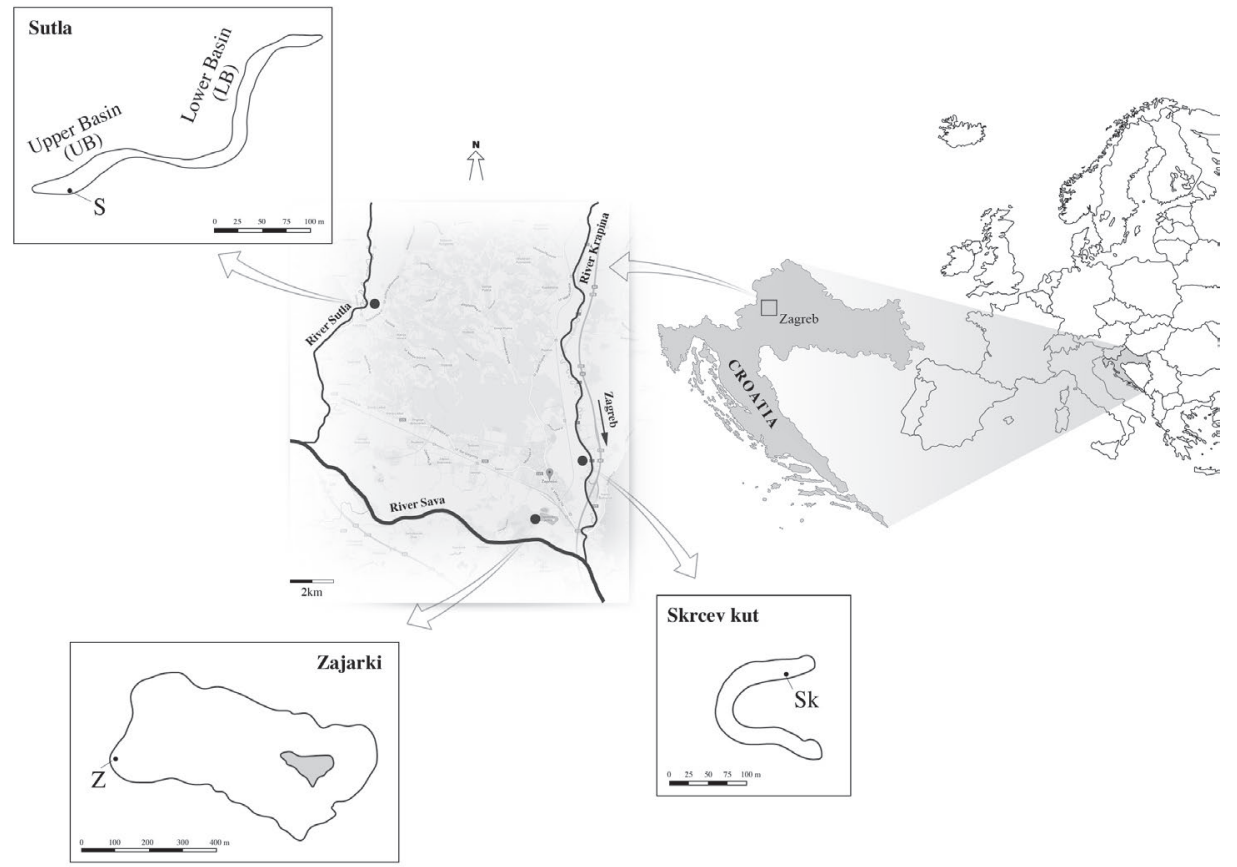

Fig. 1. Map of the investigated water bodies in North West Croatia with marked positions of sampling points in the littoral zones. S: Sutla backwater; Sk: Skrcev kut oxbow; Z: Zajarki gravel pit

\section{Field and laboratory measurements and biocoenotic analyses}

Environmental factor measurements and analyses were conducted with a procedure previously described by ŠPoljar et al. (2016). Macrophyte dry mass was measured after epiphyton was scraped off, dried in an oven at $104{ }^{\circ} \mathrm{C}$ for $24 \mathrm{~h}$ and weighed.

Planktonic, epiphytic and benthic samples were collected in the littoral zone of each waterbody during July, August and September of the year 2012 ( 3 waterbodies $\times 3$ months $\times 3$ replicates). Epiphyton was sampled from two macrophyte species differing in their stem architecture: first, the floating-leaved yellow waterlily, N. lutea, in the littoral zone of Skrcev kut oxbow and Zajarki gravel pit and second, the complex and submerged C. demersum in UB (Tab. 1a). 
For epiphyton analysis, shoots of Ceratophyllum (each sample included a shoot of a single plant) were taken with a plexiglas core sampler ( $30 \mathrm{~cm}$ high, $\varnothing 8 \mathrm{~cm}, 26 \mu \mathrm{m}$ mesh) according to KorNijów \& KaIresalo (1994), and Nuphar leaves were collected by hand. After cutting 10 to $15 \mathrm{~cm}$ long shoots of the macrophytes, the epiphyton was scraped off using a small brush and washed into the plastic bottles, one set of macrophyte shoots was scraped for the identification of microfauna (transferred to the laboratory and the living material was identified $\leq 48 \mathrm{~h}$ after collection). Another set of epiphytic samples was collected for the measurement of algal biomass. All shoots were dried off and weighed and epiphytic abundance and biomass were estimated, ind g ${ }^{-1}$ dry mass of the macrophyte (DM) and $\mu \mathrm{g} \mathrm{g}^{-1} \mathrm{DM}$, respectively.

Zooplankton samples were collected by filtering $20 \mathrm{~L}$ of the water through a plankton net $(26 \mu \mathrm{m}$ mesh) and were fixed with $4 \%$ formalin. Zooplankton comprising rotifers, cladocerans and copepods were analysed, while the epiphyton consisted of protozoans, rotifers, nematodes, gastrotrichs and oligochaetes. Zooplankton and epiphyton samples were identified and counted in three subsamples under an Opton-Axiovert 35 inverted microscope (125×to 400× magnification). For species identification, the following references were consulted: Voigt \& Koste (1978), Ogden \& Hedley (1980), Amoros (1984), Einsle (1993), Foissner \& Berger (1996), and Rundle et al. (2002). Bdelloidea and Nematoda were counted but not identified.

Macroinvertebrates were sampled from the benthos (ind $\mathrm{m}^{-2}$ ) and among the macrophytes (ind $\left.\mathrm{g}^{-1} \mathrm{DM}\right)$. Benthic macroinvertebrates were sampled using a $25 \times 25 \mathrm{~cm}$ Surber sampler $(300-\mu \mathrm{m}$ mesh). A third set of macrophyte shoots was collected for analysis of the macroinvertebrates attached to the stems (pseudoepiphytic, in the further text epiphytic macroinvertebrates). Samples were washed and sieved through a $300-\mu \mathrm{m}$ mesh net. Macroinvertebrate samples were preserved in $75 \%$ ethanol and analysed under an Olympus SZ61 stereomicroscope (10× to 40× magnification). Specimens were identified to the lowermost taxonomic level based on Hopkins (1961), KNOz (1965), RADOMAn (1983), Nilsson (1996), Nilsson (1997), Waringer \& Graf (1997), Bauernfeind \& Humpesch (2001), Glöer (2002), SundermanN \& Lohse (2004) and Timm (2009).

Biomass of protozoan and metazoan invertebrates in the plankton and epiphyton, presented in dry weight, was calculated by using the biovolume data based on their geometric shapes, and converted to dry mass for protozoans (GILBERT et al., 1998), rotifers, cladocerans and copepods (Dumont et al., 1975; Malley et al., 1989). Macroinvertebrate biomass was determined on up to 30 randomly-selected individuals per taxon in each sample after being dried in the thermostat $\left(104{ }^{\circ} \mathrm{C}\right)$.

We considered functional feeding guilds (FFG) in the plankton (rotifers, cladocerans and copepods) as microfilter-feeders, macrofilter-feeders and predators according to ŠpoLJAR et al. (2011) and macroinvertebrates were classified according to Moog (2002).

\section{Food web model properties and analysis}

To analyze the main properties of the food webs, we used equations and visualizations according to Yoon et al. (2004) and WiLliams (2010). Relationships among the invertebrate consumers (ID predator) and their food resources (ID prey, protozoan and metazoan invertebrates) were analysed through the three food webs consisting of epiphytic, planktonic and macroinvertebrate species. Main food resources were suspended phytoplankton (Ssalgae), epiphytic algae (Ealgae), suspended (SsPOM), sediment (SPOM) and epiphytic (EPOM) particulate organic matter, leaf litter (Ll), as well as protozoan and metazoan invertebrate species.

For the visualization of food webs, the relaxed niche model (RNM) introduced by Williams (2010) was selected, in which the species are placed on vertical axis $Y$ using the convention that the basal species are at trophic level one, while their direct or indirect consumers are at higher trophic levels. Elements of network model, number of trophic species $(S)$ and food resources are presented as nodes, and links (L) represent trophic interactions. Common properties of each food network model are analysed in this study: connectivity $(\mathrm{L} / S)$, number of link per species; connectance $\left(\mathrm{C}, \mathrm{L} / \mathrm{S}^{2}\right)$, the number of links; web complexity (SC) estimated as product $S \times C$ (PoLIs, 1991); the mean trophic level (TL) of all species computed using the short-weighted trophic level algorithm (Williams \& Martinez, 2008) and predator:prey richness ratio (PPR), number of predatory taxa/number of prey taxa (Dézerald et al., 2013). In the presented food webs, species of some systematic groups were associated in one trophic node as follows: Testacea and Gymnoamoeba as Sarcodina on S and Sk, Ciliophora on S and Sk, and Gastropoda, Oligochaeta and Hydrachnidia on S, Sk and Z (see supporting information in Appendix S1). Copepod larvae, nauplii and copepodites were each classified as a separate node due to their different food resources through the development. 
Tab. 1. Main characteristics of the investigated water bodies (a) and results of the Kruskal-Wallis test $\left(\mathrm{H}_{(2,9)^{\prime}} p<0.05\right)$ and post hoc multiple comparison test for the environmental variables (b)

a)

\begin{tabular}{|c|c|c|c|}
\hline Localities & Sutla (S) & Skrcev kut (Sk) & Zajarki (Z) \\
\hline \multirow{2}{*}{ Coordinates } & $45^{\circ} 54^{\prime} 51^{\prime \prime} \mathrm{N}$ & $45^{\circ} 51^{\prime} 45^{\prime \prime} \mathrm{N}$ & $45^{\circ} 50^{\prime} 36^{\prime \prime} \mathrm{N}$ \\
\hline & $15^{\circ} 42^{\prime} 11^{\prime \prime} \mathrm{E}$ & $15^{\circ} 49^{\prime} 29^{\prime \prime} \mathrm{E}$ & $15^{\circ} 48^{\prime} 78^{\prime \prime} \mathrm{E}$ \\
\hline Length $_{\text {max }}(\mathrm{m})$ & 260 & 300 & 750 \\
\hline Width $_{\text {max }}(\mathrm{m})$ & 20 & 12 & 310 \\
\hline Depth $_{\text {max }}(\mathrm{m})$ & 3 & 2 & 6 \\
\hline Littoral zone depth (m) & $1.43 \pm 0.83$ & $0.50 \pm 0.10$ & $0.53 \pm 0.31$ \\
\hline Area $\left(\mathrm{m}^{2}\right)$ & 2500 & 2500 & 31000 \\
\hline Macrophyte coverage (\%) & $70-80$ & $30-40$ & 10 \\
\hline Type of macrophytes & Submerged & Floatant & Floatant \\
\hline Species & Ceratophylllum demersum & Nuphar lutea & Nuphar lutea \\
\hline $\mathrm{TSI}_{\mathrm{SD}}$ & $55 \pm 1.20$ & $69 \pm 3.75$ & $49 \pm 0.46$ \\
\hline $\mathrm{TSI}_{\mathrm{TP}}$ & $91 \pm 1.27$ & $91 \pm 0.89$ & $83 \pm 0.89$ \\
\hline $\mathrm{TSI}_{\mathrm{Chla}}$ & $53 \pm 4.69$ & $61 \pm 1.28$ & $35 \pm 4.8$ \\
\hline Anthropogenic impact & $\begin{array}{l}\text { Leaching from the } \\
\text { agricultural field }\end{array}$ & $\begin{array}{l}\text { Leaching from the } \\
\text { agricultural field, sport } \\
\text { fishing }\end{array}$ & $\begin{array}{l}\text { Arranged coast for sport } \\
\text { fishing and recreation }\end{array}$ \\
\hline
\end{tabular}

TSI - trophic state index

b)

\begin{tabular}{|c|c|c|c|c|c|c|}
\hline \multirow{2}{*}{ Environmental variables } & Sutla (S) & Skrcev kut (Sk) & Zajarki (Z) & \multirow{2}{*}{$\mathrm{H}$} & \multirow{2}{*}{$\mathrm{p}$} & \multirow{2}{*}{$\begin{array}{c}\text { Multiple } \\
\text { comparison }\end{array}$} \\
\hline & Mean \pm SD & Mean \pm SD & Mean \pm SD & & & \\
\hline Transparency, SD (m) & $1.40 \pm 0.20$ & $0.53 \pm 0.21$ & $2.07 \pm 0.12$ & 7.26 & 0.003 & $\mathrm{Z}>\mathrm{Sk}$ \\
\hline Conductivity $\left(\mu \mathrm{S} \mathrm{cm}^{-1}\right)$ & $343.33 \pm 19.73$ & $369.67 \pm 29.40$ & $537.33 \pm 36.09$ & 6.49 & 0.04 & $Z>S$ \\
\hline $\mathrm{COD}_{\mathrm{Mn}}\left(\mathrm{mg} \mathrm{O}_{2} \mathrm{~L}^{-1}\right)$ & $17.59 \pm 5.26$ & $18.75 \pm 1.59$ & $6.82 \pm 2.87$ & 7.2 & 0.03 & $\mathrm{Sk}>\mathrm{Z}$ \\
\hline Chlorophyll a plankton $\left(\mu \mathrm{g} \mathrm{L}^{-1}\right)$ & $37.10 \pm 21.70$ & $27.43 \pm 14.26$ & $3.65 \pm 2.81$ & 5.8 & 0.054 & \\
\hline \multirow[t]{2}{*}{ Chlorophyll $a$ epiphyton $\left(\mu g_{g} \mathrm{DM}^{-1}\right)$} & $63.14 \pm 45.33$ & $15.02 \pm 6.50$ & $8.09 \pm 6.54$ & 3.8 & 0.058 & \\
\hline & \multicolumn{6}{|c|}{ All localities $(\mathrm{S}, \mathrm{Sk}, \mathrm{Z}) \mathrm{p}>0.05$} \\
\hline Temperature $\left({ }^{\circ} \mathrm{C}\right)$ & \multicolumn{6}{|c|}{$24.00 \pm 4.90$} \\
\hline Dissolved oxygen $\left(\mathrm{mg} \mathrm{L}^{-1}\right)$ & \multicolumn{6}{|c|}{$8.58 \pm 2.33$} \\
\hline $\mathrm{pH}$ & \multicolumn{6}{|c|}{$8.15 \pm 0.43$} \\
\hline Orthophosphates, $\mathrm{PO}_{4}^{3-}=\mathrm{P}\left(\mathrm{mg} \mathrm{L}^{-1}\right)$ & \multicolumn{6}{|c|}{$0.05 \pm 0.02$} \\
\hline Nitrates, $\mathrm{NO}_{3}^{-}-\mathrm{N}\left(\mathrm{mg} \mathrm{L}^{-1}\right)$ & \multicolumn{6}{|c|}{$0.72 \pm 0.82$} \\
\hline Nitrites, $\mathrm{NO}_{2}^{-}-\mathrm{N}\left(\mathrm{mg} \mathrm{L}^{-1}\right)$ & \multicolumn{6}{|c|}{$0.01 \pm 0.01$} \\
\hline Ammonia, $\mathrm{NH}_{3}-\mathrm{N}\left(\mathrm{mg} \mathrm{L}^{-1}\right)$ & \multicolumn{6}{|c|}{$0.12 \pm 0.05$} \\
\hline Total nitrogen $\left(\mathrm{mg} \mathrm{N} \mathrm{L}^{-1}\right)$ & \multicolumn{6}{|c|}{$1.42 \pm 0.71$} \\
\hline Total phosphorus (mg P L-1) & \multicolumn{6}{|c|}{$0.29 \pm 0.12$} \\
\hline $\begin{array}{l}\text { Suspended organic matter } \\
\left(\mathrm{mg} \mathrm{AFDM} \mathrm{L}^{-1}\right)\end{array}$ & \multicolumn{6}{|c|}{$0.01 \pm 0.001$} \\
\hline
\end{tabular}


Eleven properties of the RNM are compared among the three food webs $B, I$ and $T$ : the proportions of basal (without prey), intermediate (with both predators and prey) and top (without predators) species; GenSD, VulSD, LinkSD, the normalized standard deviations of generality (the number of taxa a species eats), vulnerability (the number of taxa that feed on a species) and the number of consumers, resources, and consumers plus resources across the species. Connectance; MeanSim, the mean Jacardian similarity (Martinez, 1991); PathLen, the mean characteristic path length between species (WiLliams et al., 2002); MeanShortChn, the mean shortest chain to a basal species and Cluster, the mean clustering coefficient (WiLliams et al., 2002). For the analysis of prey vulnerability, the species were divided into four groups regarding their size categories and lifestyle: Ie, epiphytic protozoans; Ile, epiphytic metazoans; IIp, zooplankton and IIIlb, macroinvertebrates (Tab. S1).

Comparing the empirical food-web structure with that produced by the niche model, we generated a set of a 1000 niche-model web (Dunne et al., 2008; Williams \& Martinez, 2008). Based on the eleven properties of each network, we calculated niche model error, $\mathrm{ME}$, to determine whether the value of a property in an empirical food web differs significantly from the model's distribution of values for that property; ME Mean is the average of ME means across 11 network properties, ME SD is the standard deviation of ME; $|\mathrm{ME}|$ is the proportion of MEs that fall outside \pm 1 (DunNe et al., 2008).

\section{Data analysis}

The mean values of triplicates across estimated variables were considered for the analyses ( 3 waterbodies $\times 3$ months, $n=9$ ). The trophic state index was determined according to Carlson (1977) based on water transparency $\left(\mathrm{TSI}_{\mathrm{SD}}\right)$.

For biocoenotic and environmental analyses, all data were logarithmically transformed $\left[\log _{10}(\mathrm{x}+\right.$ 1)] and their normality was checked using the Shapiro-Wilk test. The data of biomass were normally distributed and were compared by one-way ANOVA and post hoc Tukey's HSD test. As the rest of the data (abundance, diversity) did not follow a normal distribution even after transformation, the Kruskal-Wallis test (comparison between multiple independent samples for spatial distribution of environmental parameters and biotic components) accompanying post hoc multiple comparisons were implemented using Statistica 13.1 (Statsoft, Inc. 2015). Expectedly, as sampling was performed in a limited time period, no temporal oscillations of environmental and biocenotical parameters were established (Kruskal-Wallis test, $p>0.05$ ), thus the analyses were focused on spatial/habitat peculiarities.

Multivariate analysis of similarities (ANOSIM) was used to identify differences/similarities in environmental conditions among the three water bodies employing the analytical package PRIMER v6 (CLARKe \& Gorley, 2006). ANOSIM generates a value of $R$ ranging between -1 and +1 ; a value of zero indicates no difference among a set of samples (CLARKE \& WARWICK, 2001). The relationships between: (1) the biomass and diversity of epiphyton (sarcodins, ciliates and rotifers), plankton (rotifers, cladocerans, nauplii and copepodites+adults) and epiphytic macroinvertebrate species, e.g., small snails and insect larvae against (2) the biomass of main benthic macroinvertebrates feeding guilds (grazers, active filtrators and predators) and environmental parameters (transparency and food resources), were explored by redundancy analysis (RDA) based on the logarithmically-transformed data. Prior to this, a detrended correspondence analysis (DCA) was performed and, as the data showed a linear response, the RDA was applied (TER BRAAK \& ŠMILAUER, 2002). Statistical significance of the impacts of the macroinvertebrates and environmental parameters on the littoral plankton and epiphyton was tested by Monte Carlo permutation test (499 permutations).

\section{RESULTS}

\section{Environmental parameters}

Overall, values of the environmental parameters significantly differed among the water bodies (ANOSIM, $r=0.60, p=0.01$;). Transparency and conductivity were significantly higher in $\mathrm{Z}$, while DOM values were notably higher in Sk. Trophic levels accounted as TSI ${ }_{S D}$ had maximum values in Sk and lowest in $Z$. The highest food resources for algivores were determined in plankton and epiphyton of the littoral zone in $\mathrm{S}$ (Tab. 1b).

\section{Biodiversity}

In total, 167 taxa (90 microfauna and 77 macroinvertebrates) of benthos, plankton and epiphyton were recorded during the study period among the macrophytes in the littoral zones of the three shal- 
low water bodies (see Tab. S1). Only 25 taxa (16\%) were common for all the three study sites; among these, 20 belonged to microfauna. Biodiversity assessment resulted in significant difference across the three water bodies (Kruskal-Wallis test $\left.\mathrm{H}_{(2,9)}=6.489, p=0.04\right)$. The highest diversity $(127$ taxa) was notified in the backwater $S$ within the submerged macrophyte Ceratophyllum, and an almost twice as low diversity was registered in Sk and Z within floating-leaved Nuphar; 73 and 59 taxa, respectively. Plankton diversity did not differ significantly among the studied waterbodies (Kruskal-Wallis, $p>$ 0.05). With regard to the epiphytic entities, the water bodies of higher trophic levels, S and Sk, reached higher diversity than Z. Macroinvertebrates reached the highest diversity within submerged macrophytes in S (Fig. 2).
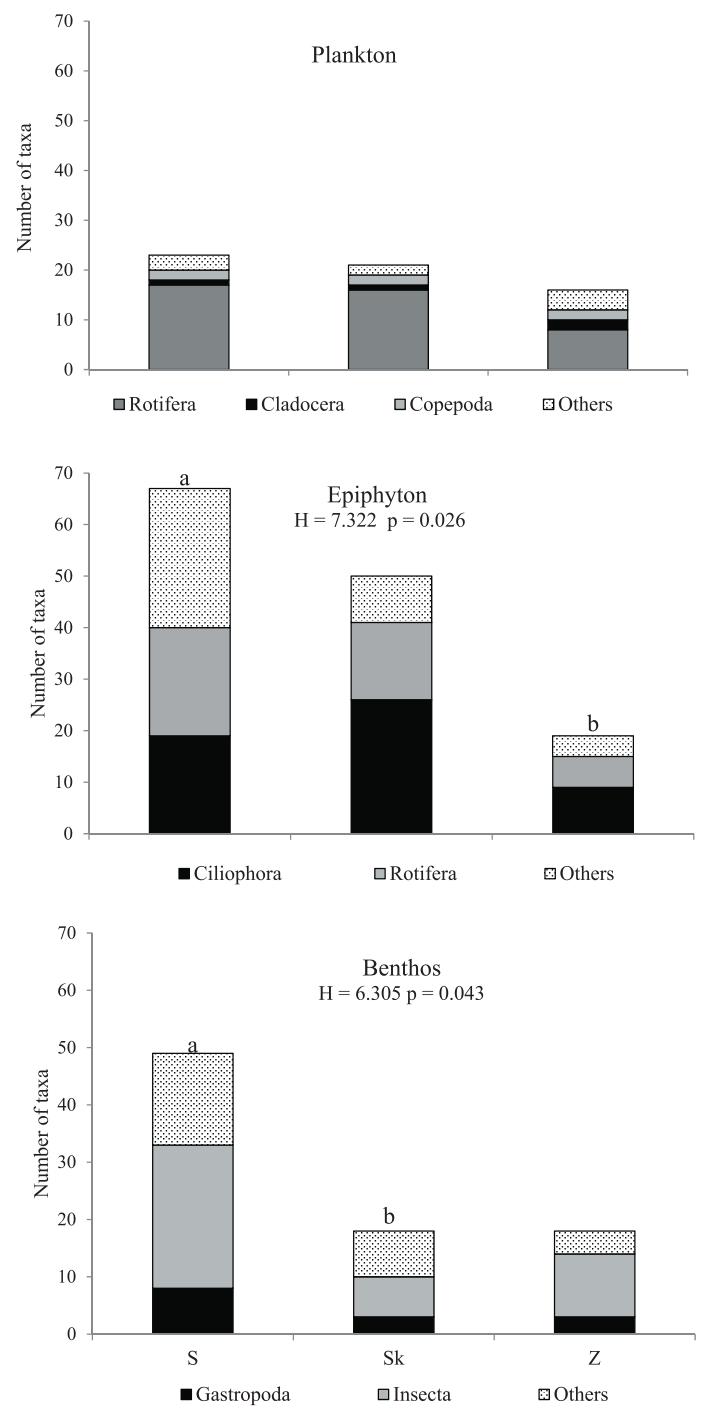

Fig. 2. Biodiversity variations of the dominant biocoenotic groups (plankton, epiphyton and benthos) across the three water bodies. Significant differences were realized by Kruskal-Wallis test $\left(\mathrm{H}_{(2,9)^{\prime}}, p<\right.$ $0.05)$. 


\section{Abundance and biomass}

Rotifers constituted the greatest abundance of the littoral zooplankton in $\mathrm{Z}$ and $\mathrm{Sk}, \sim 46 \%$ and $\leq$ $96 \%$, respectively (Fig. 3). There was almost ten fold higher abundance of rotifers in Sk ( $2170 \pm 562$ ind $\left.\mathrm{L}^{-1}\right)$ than in $\mathrm{Z}\left(295 \pm 70\right.$ ind $\left.\mathrm{L}^{-1}\right)$. This was due, in part, to the populations of Keratella tecta $(771 \pm 606$ ind $\left.\mathrm{L}^{-1}\right)$ and Trichocerca similis $\left(225 \pm 93\right.$ ind $\left.\mathrm{L}^{-1}\right)$. Planktonic rotifers represented $90 \%$ of the abundance in Sk, and considerably less, $44 \%$ and 32\%, in S and Z, respectively (see Tab. S1). Littoral species took over larger part of abundance in the two latter water bodies: i.e. bdelloids in S and Z, $296 \pm 131$ ind L-1 and $29 \pm 5$ ind $\mathrm{L}^{-1}$, respectively. Submerged macrophytes in $\mathrm{S}$ hosted the most abundant cladoceran population (Fig. 3).
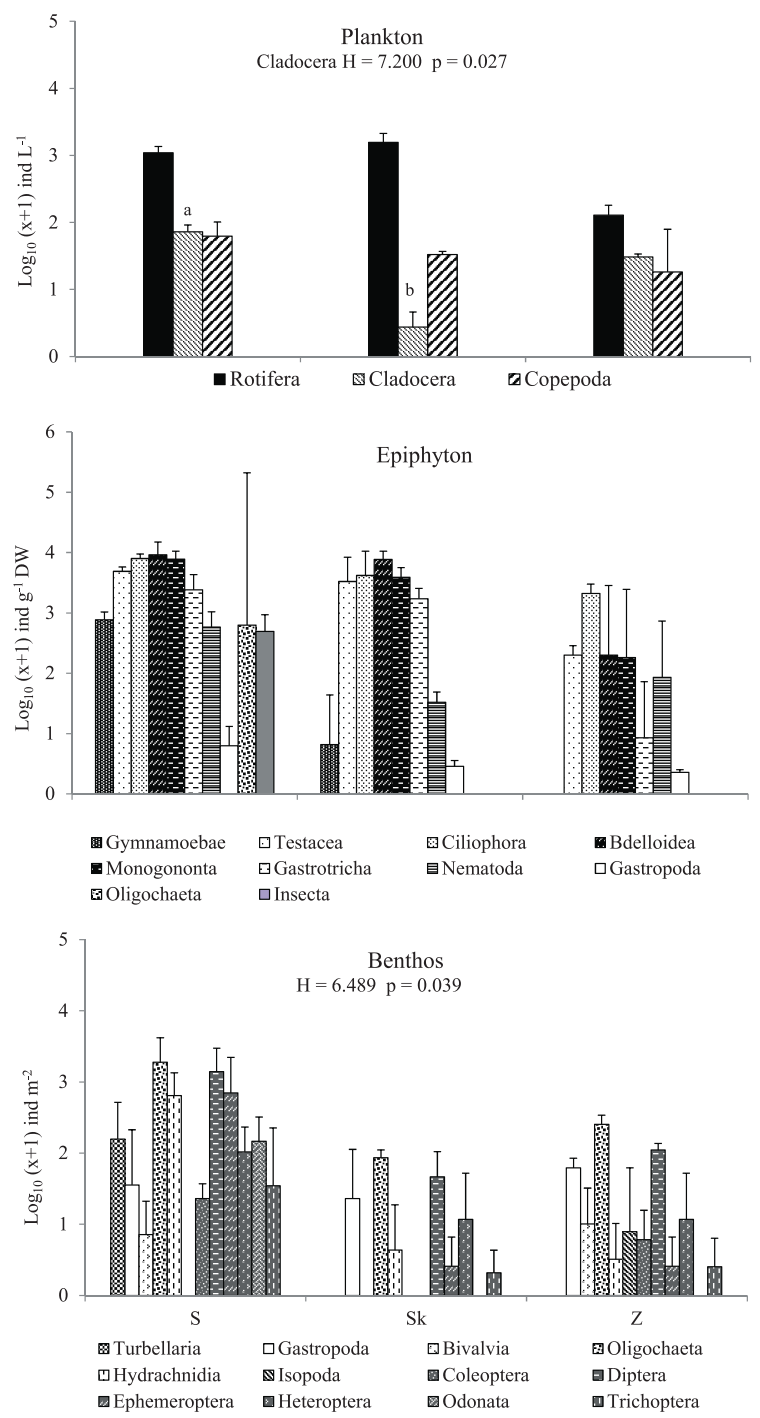

Fig. 3. Oscillations of abundances $\left(\log _{10(x+1)}\right)$ in plankton, epiphyton and benthos across three water bodies. Significant differences were realized by Kruskal-Wallis test $\left(\mathrm{H}_{(2,9)} p<0.05\right)$. 
Epiphyton, composed of protozoans, microscopic metazoans and macroinvertebrates (gastropods and insect larvae) developed the most diverse and abundant populations over submerged macrophyte stems in S. The bdelloids reached a density of $11124 \pm 4044$ ind $\mathrm{g}^{-1} \mathrm{DM}$, while among MZB in S most abundant were dipteran insect larvae and heteropterans (Fig. 3, Tab. S1). Benthic macroinvertebrates exhibited significantly higher abundances in sediments covered with the submerged Ceratophyllum in S, except gastropods, with increased abundance in Z (Fig. 3).

Planktonic biomass ranged from $10^{-5} \mathrm{~g} \mathrm{~L}^{-1}$ to $10^{-3} \mathrm{~g} \mathrm{~L}^{-1}$. Copepods achieved three (S and Sk) to eleven $(Z)$ fold higher biomass than the two other planktonic groups (Fig. 4). The microhabitats in $S$ held significantly higher biomass of planktonic algivorous cladocerans (ANOVA $F=11.84, p<0.005$; Tukey's HSD) than Sk. Among the epiphytic metazoans, biomass of rotifers and nematodes was the most prominent. We noted that the complex macrophyte stands in S were favourable habitats for 21 predatory macroinvertebrate species, including turbellarians, phantom midges, notonectids, water mites, heteropterans and majority of dipteran larvae (Tab. S1). Decrease in biomass of the predators was significantly related to the reduction of habitat complexity (ANOVA $F=9.85, p<0.05, S>S k, Z$; Tukey's HSD test). Among macroinvertebrates over macrophytes and in littoral sediment, grazers and detritivores also shared a considerable part (Fig. 4).
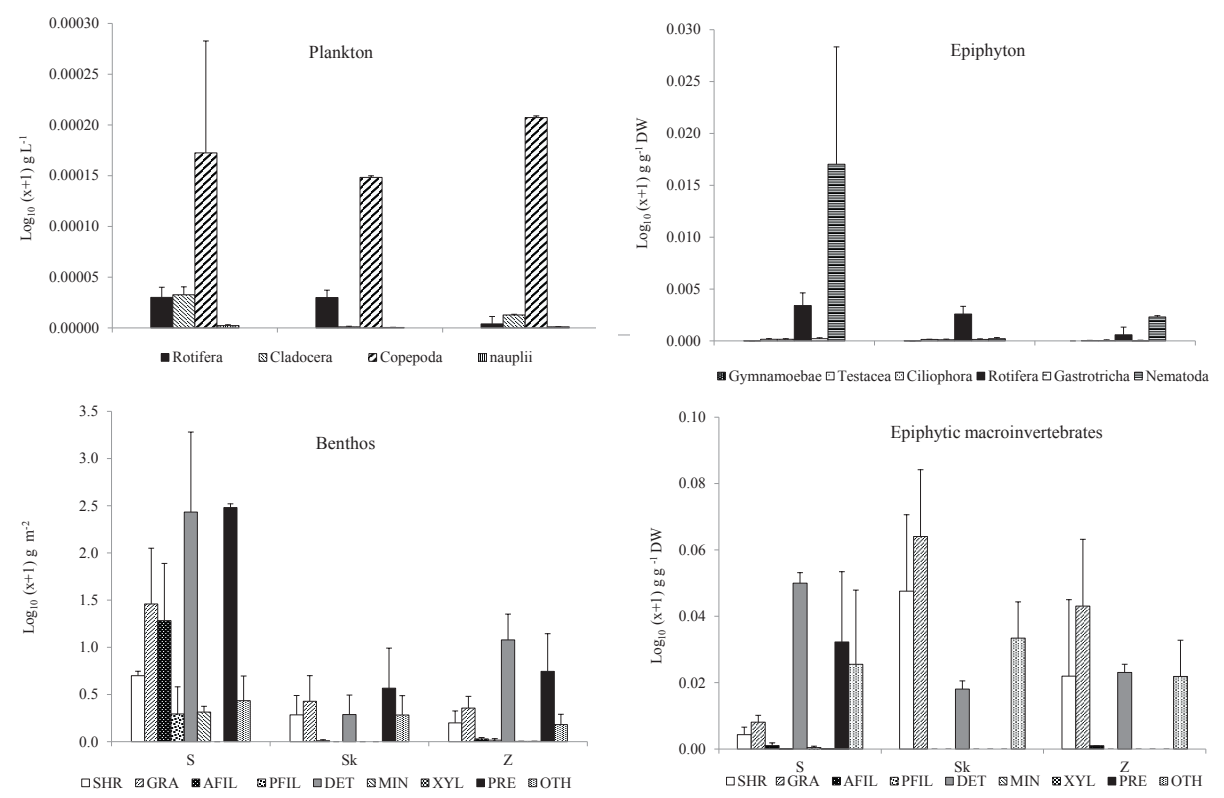

Fig. 4. Oscillations of the biomass $\left(\log _{10(x+1)}\right)$ for dominant groups in zooplankton, epiphyton and functional feeding guilds for epiphytic macroinvertebrates over macrophytes and in benthos across three water bodies. SHR: shredders; GRA - grazers, AFIL - active filterers, PFIL - passive filterers, DET - detritivores, MIN - miners, XYL - xylophage, PRE - predators, OTH - others.

\section{Interactions of environmental variables and biotic components}

The first two axes of the RDA plot explain $94 \%$ of variance, $76 \%$ and $15 \%$, respectively. According to the Monte Carlo permutation test, macrophyte coverage $(F=12, p=0.002)$ and biomass of the macroinvertebrate predators $(F=5.4, p=0.02)$ explained $63 \%$ and $18 \%$ of variance, respectively, and significantly impacted the microfaunal biomass and diversity in the littoral zones (Fig. 5). Most of the evaluated factors strongly related to axis $1(r=-0.6$ to -0.91$)$. Diversity and biomass of the epiphytic groups were positively affected by food resources and macrophyte structural complexity. Biomass of pelagic rotifers among the macrophyte stands was negatively affected by pelagial transparency, while water transparency increased the diversity of benthic invertebrates and the biomass of pelagic copepods and cladocerans. Increased suspended organic matter and epiphytic algae enhanced the biomass of benthic grazers and detritivores $(r=0.65$ to 0.75$)$. 


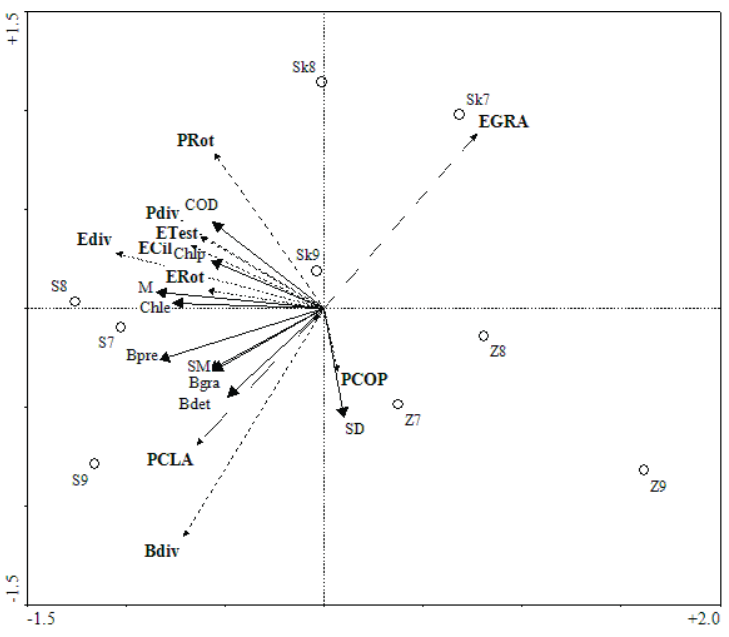

Fig. 5. The triplot of the redundancy analysis (RDA) indicating the interactions between the diversity of each biocenotic constituent, biomass of microfauna and epiphytic grazers (dash line) against environmental conditions and biomass of the benthic macroinvertebrates (solid line). Abbreviations: benthic (Bdiv), epiphytic (Ediv) and planktonic diversity (Pdiv); planktonic Rotifera (PROT), Cladocera (PCLA) and Copepoda (PCOP); epiphytic Testacea (ETes), Ciliophora (ECil), Rotifera (Erot) and grazers (EGRA); Transparency (SD), benthic grazers (Bgra), detritivores (Bdet) and predators (Bpred); phytoplankton biomass (Chlp), epiphytic algae biomass (Chle), dissolved organic matter (DOM), suspended organic matter (SM), macrophytes (M).

\section{Food webs properties and interactions}

Relaxed niche food-web models obtained between 41 and 83 trophic taxa (Fig. 6). Diversity, expressed as number of taxa, reduced in trophic species $(S)$ up to $35 \%$. The largest web size, linkage and complexity were evidenced in the Sutla backwater and decreased with reduction in habitat heterogeneity (Tab. 2). Connectance varied around $0.11 \pm 0.02$, and positively related to species generality $(r=$ $0.641, p<0.001)$ and vulnerability $(r=0.512, p<0.0001)$. Thus, maximum $C$ value was observed in Sk with the highest fraction of top predatory species among the estimated food webs. Otherwise, connectance negatively related to PPR $(r=-0.77, p>0.05)$. The ratio of $T: I: B$ taxa mostly remained constant among the studied food webs, with a remarkable share of intermediate taxa (Tab. 3). Differences in properties between original and modelled food webs with significantly under- or overestimated values are shown in Tab. 3. The niche model tended to underestimate property values in S and Sk, while the property values were slightly overestimated in Z, mean MEs0.003 to 0.340 (Tab. 4).

Tab. 2. Basic properties of the food webs in the littoral zone of three water bodies. All abbreviations are explained in the section Materials and methods.

\begin{tabular}{|c|c|c|c|c|c|c|}
\hline Food Web & Sutla & Skrcev kut & Zajarki & BS & LRL & SP \\
\hline Diversity & 127 & 73 & 59 & 85 & 181 & 35 \\
\hline S & 83 & 43 & 41 & 79 & 92 & 25 \\
\hline L & 732 & 239 & 162 & 378 & 994 & 198 \\
\hline L/S & 8.82 & 5.56 & 3.95 & 4.45 & 10.8 & 7.9 \\
\hline C & 0.106 & 0.129 & 0.096 & 0.052 & 0.118 & 0.315 \\
\hline SC & 17.85 & 11.38 & 8.1 & 9 & 21.61 & 16.5 \\
\hline TL & 2.47 & 2.28 & 2.21 & & & \\
\hline Tac/Totpred & 0.72 & 0.31 & 0.50 & & & \\
\hline PPR & 0.57 & 0.46 & 0.52 & & & \\
\hline$P_{\text {Tac }}$ PR & 0.42 & 0.17 & 0.29 & & & \\
\hline
\end{tabular}

LRL, Little Rock Lake (Martinez, 1991); SP, Skipwith Pond (Warren, 1989); BS, Broadstone Stream (Schmid-Araya et al., 2002b) 
a)

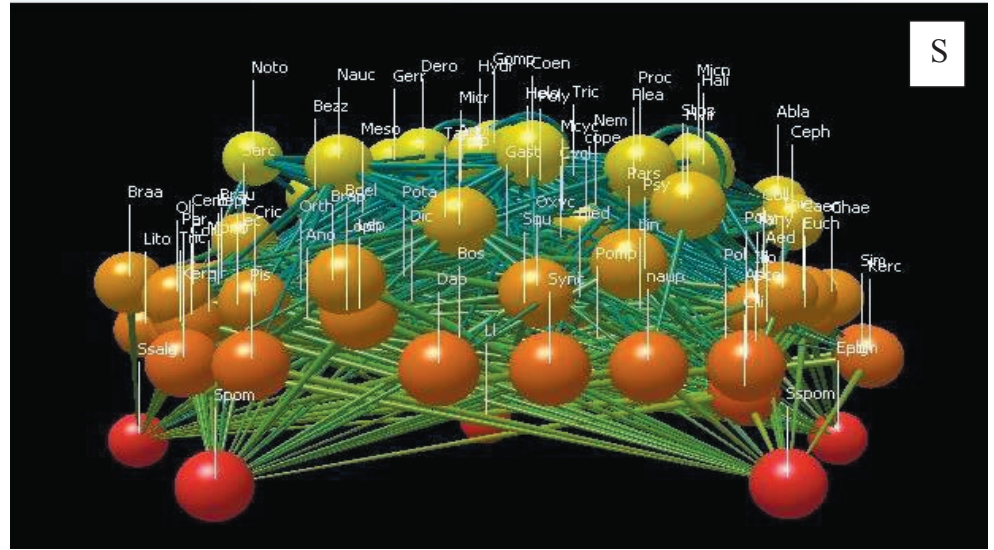

b)

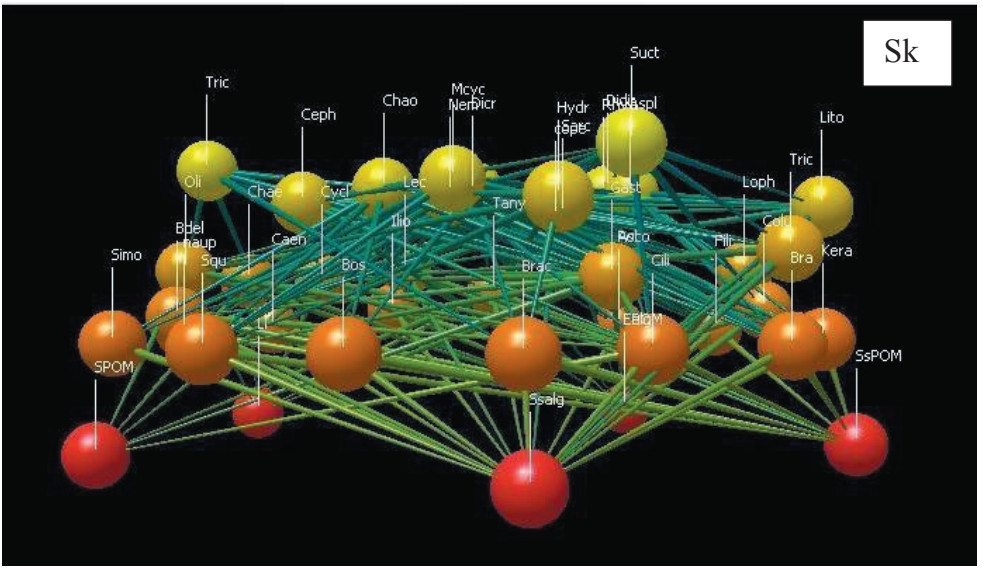

c)

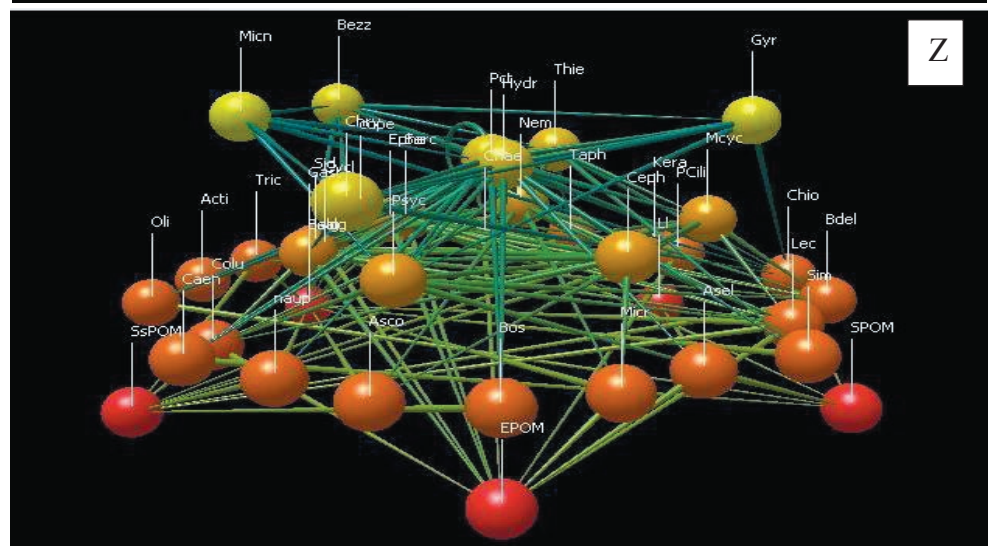

Fig. 6. Relaxed niche model of the food webs based on the original species in the littoral zone of Sutla backwater (S), Skrcev kut oxbow (Sk) and Zajarki gravel pit (Z). Spheres represent trophic species and elongated cones represent feeding links. Position of the taxa vertically corresponds to their trophic level (TL) with basal taxa (primary producers and detritus) shown at the bottom of the network in red, and uppermost taxa at the top in yellow. For species abbreviations consult Table S1. Main food resources were suspended phytoplankton (Ssalgae), epiphytic algae (Ealgae), suspended (SsPOM), sediment (SPOM) and epiphytic (EPOM) particulate organic matter and leaf litter (L1). 
The mean values of prey vulnerabilities for epiphytic metazoans (IIe, i.e. Colurella, Lecane, Lepadella and gastrotrichs) and planktonic (IIp) species were significantly high (ANOVA $F=3.9-7.0, p<0.05$ ) in comparison with the protozoans (Ie) and epiphytic macroinvertebrates (IIIb) (Fig. 7). Prey vulnerability for each life type and size category of IIe, IIp or IIIb was significantly higher among the complex submerged macrophyte stands in S (ANOVA $F=4.5-8.5, p<0.05$ ) than in the floating-leaved stands of Sk and Z.

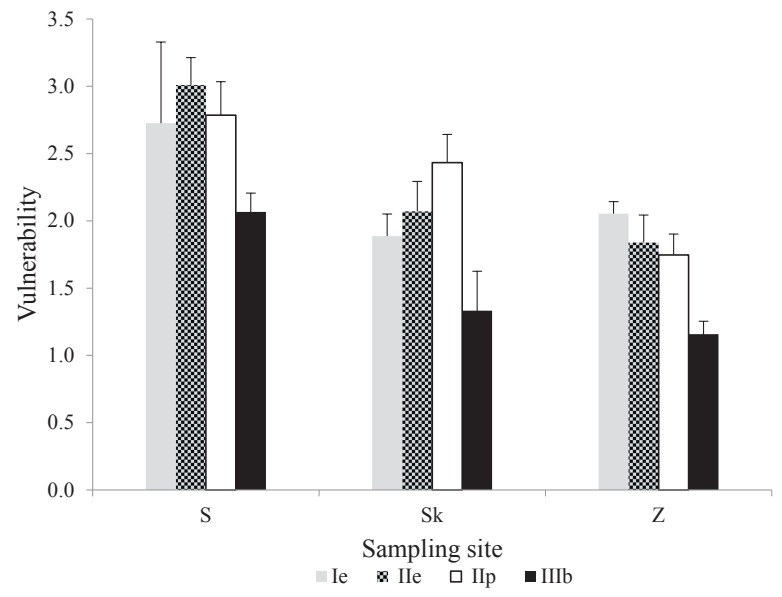

Fig. 7. Prey vulnerability are graded into size categories (I-III) and life style (epiphytic (e), planktonic (p) and benthic(b)) based on the observed food webs in Sutla backwater (S), Skrcev kut oxbow (Sk) and Zajarki gravel pit (Z).

\section{DISCUSSION}

Studying complex trophic interactions in diverse water systems is challenging, but recenttly more attention has been drawn toward the discovery of such interactions (MARTINEZ, 1991; SCHMID-Araya et al., 2002a; Dunne et al., 2008; Сомрте et al., 2016). In the current study, we attempted to define trophic interactions by taking into account the basic ecological components, i.e., organism biodiversity, abundance and biomass, environmental variables and functional feeding guilds connected in the interpretation of food web complexity. The results of our study confirmed that in macrophyte stands of higher complexity zooplankton could find short-time refuge from visual predators, i.e. fish, However, among macrophytes, zooplankton simultaneousy encounters macroinvertebrate predators, occupying a significant trophic niche to higher trophic level in shallow water bodies.

Higher concentrations of DOM in the Sutla and Skrcev kut could be explained by the decomposition of considerable algal biomass in plankton and epiphyton, and also by the decay of macrophyte stems and probably due to resuspension as a result of the proximity of the sediment (Špoljar et al., 2012 a,b; BRothers et al., 2013). We assumed that the highest water transparency in Zajarki gravel pit and minimum Chl $a$ and dissolved organic matter was an indication of low productivity. Domination of detritivores (i.e. Keratella and Bosmina) in the zooplankton appears to support ongoing organic matter decomposition, which complies with the results obtained by Šroljar et al. (2012a).

The structural heterogeneity of habitats in the Sutla backwater related to the complex macrophyte architecture, significantly enhanced the biodiversity (KUCZYŃSKA-KIPPEN, 2003; ŠPOLJAR et al., 2012a; Chaparo et al., 2015; DražInA et al., 2016), as different from the structural simplicity and biodiversity scarcity in Zajarki gravel pit (ŠPOLJAR et al., 2011, ŠPOLJAR, 2013). Snails, water mites and insect larvae are the main consumers of epiphyton (Liboriussen et al., 2005), maintain macrophyte light conditions i.e. stands, thus increase the diversity of benthic macroinvertebrates among the macrophyte stems. On the other hand, the substantial decline in macroinvertebrate diversity corresponded significantly to a reduction in the structural heterogeneity in the water bodies; this is similar to the results of studies on Lago di Candia, northern Italy (CREMONA et al., 2008) and peat ditches in the Netherlands (Whatley et al., 2014). Rotifers and ciliates, which comprised a considerable proportion of the plankton and 
epiphyton diversity, did not differ significantly among the studied water bodies. Both of these organisms have high dispersal ability due to their small body size and dormant stages, showing broad distributions typical for microscopic organisms (Fontaneto et al., 2008; WAllace et al., 2008). Spatial distribution of plankton, epiphyton and macroinvertebrate abundances and biomasses accorded with their diversity pattern, the highest values of which occurred in the Sutla backwater with complex submerged Ceratophyllum stands. This phenomenon was also noticed in previous studies (KUCZYŃsKAKippen, 2003; Meerhoff et al., 2003; Estlander et al., 2009; Šroljar et al., 2012a,b).

Results of the RDA suggested that planktonic cladocerans in littoral zone were strongly affected by macroinvertebrate predation, and rotifers were not directly affected by predation upon the macroinvertebrates. Roмо et al. (2004) by conducting mesocosm experiments confirmed that macroinvertebrate predators attacked planktonic crustaceans, especially cladocerans and their nauplii. Our findings are also in accordance with the results of Gonzalez SAGRARIo et al. (2009) who employed both in situ and laboratory experiments to show that Buenoa sp. (backswimmer), adult Palemonetes argentinus (grass shrimp) and Cyanallagma interruptum (damselfly) controlled the abundance of cladocerans and copepods. However, copepods' escape strategies and their higher swimming velocities than cladocerans, have given them better adaptation against predators (ChApArro et al., 2015). HAMpton \& GiLberT (2001) suggested that macroinvertebrate predation could be pronounced, especially in the littoral zone or in fishless water bodies. They explained that the predatory insects, the notonectids Notonecta lunata and Buenoa macrotibialis, the smaller hemipteran Neoplea striola and the small (1.5 mm-long) aeschnid dragonfly are capable of direct suppression of rotifer populations, represented by Hexarthramira, Plationus patulus and small and large Synchaeta pectinata. This predator-prey interaction together with the habitat structure influences the prey density, and confirmed that the role of structurally-complex macrophytes as refuge for prey organisms is pronounced (WAFRE \& BARMUTA, 2004).

According to WARren (1989), food webs are not static entities, either seasonally nor spatially. However, there is a strong persistence in the organization of trophic links where natural communities display non-random interaction patterns (Dunne et al., 2008; DÉzerald et al., 2013). Many food-web studies performed in both terrestrial (e.g. grasslands and rainforest) and aquatic (freshwater and marine) environments suggest that network robustness increases with connectance (DuNNE et al., 2002; Thompson et al., 2012). In comparison with surveys conducted by Martinez (1991) in Little Rock Lake (USA) and Schmid-Araya et al. (2002b) in different ecosystems across the UK, our biocoenotic analysis was conducted over small spatial distances, within short time periods, and among shallow water bodies with slight habitat differences. The empirical data-sets collected in this study could be used for further food web simulations and could contribute to comparative studies among diverse ecosystem networks (BAsсомтте, 2009). Food web topologies can be sensitive to sampling effort (Martinez et al., 1999) and taxonomical resolution (Martinez, 1992). As is shown by clustering the investigated food webs, taxonomical resolution impacts network size and complexity and determines the food web topology. High taxonomical resolution significantly decreased connectance, as evidenced particularly in the Sutla food web and in the former study of Broadstone Stream (Schmid-Araya et al., 2002a). The medium values of connectance $(0.01$ to 0.13 ) obtained in this study are in agreement with the typical range published for food webs, 0.05 to 0.3 (Thompson et al., 2012).

The mean niche errors indicate that the niche models are consistent with prior results for Skipwith Pond and Little Rock Lake (Dunne et al., 2008; Williams \& Martinez, 2008). Fractions of top, intermediate and basal species corresponded with the well-resolved food webs in Broadstone Stream and the two latter water bodies (WARren, 1989; MArtinez, 1991; Schmid-Araya et al., 2002a). The small proportion of basal species is a result of unthorough classification of food resources, i.e. POM and algae (BRIAND \& COHEN, 1984). The increase in total invertebrate predators as well as in the tactile macroinvertebrate predators was observed in water bodies of higher transparencies, Sutla backwater and Zajarki gravel pit, probably as a consequence of reinforced fish predation in the pelagial (ŠPOLJAR et al., 2011, 2016). The enhanced proportion of predators reduces connectance, as was witnessed by the results of our study and those of PPR in tank-bromeliad ecosystems in French Guiana (DézerALD et al., 2013). Our results suggest the importance of epiphytic microfauna and zooplankton as the preferable prey among invertebrates. We observed that the vulnerability of microfauna increased with habitat complexity that favours inhabitation of numerous predatory invertebrates. WARFE \& BARMUTA (2004) revealed that macroinvertebrate abundance and diversity increase with macrophyte density and biomass. Also, macroinvertebrate abundance is positively correlated with epiphyton biomass (CATTANEO et al., 1998), indicating that this food source has a direct impact on the invertebrate community, while it is indirectly beneficial for fish colonisation, due to trophic cascade. 
We observed the complementarity of the applied multilevel analyses, i.e. community, ecosystem and food web ecology, for the biocoenotic assemblage and their interactions in the shallow lakes. Community survey enriches the knowledge about the role of microhabitats in supporting the biodiversity, but leaves unanswered the question of energy flow within the system. The food-web approach provides general rules regarding the balance among its main constituents, applicable for each ecosystem. However, in the study of the functional feeding groups, the importance of individual species may be masked. Furthermore, while networks are associated with biodiversity and energy flow, high taxonomical resolution may decrease the network connectance. As a result, information about the interactions of some species is lost within the large-sized webs. To achieve a better understanding of the details of these interactions, studies on feeding interactions are the most accurate approaches under controlled experimental conditions. This study showed that habitat can alter food web properties even at a small spatial scale and with limited structural heterogeneity. It was intended to augment our knowledge of different biocoenotic features by resolving food webs' structure. Such investigations are essential for in-depth discovery of ecosystem disturbance and environmental changes.

\section{ACKNOWLEDGMENTS}

The authors are grateful to Dr. Robert Wallace for his valuable comments on the food web analysis. We thank Svjetlana Vidović for her assistance in the field study and laboratory analyses and Predrag Belušić for his help with the editing of the figures.

Received October 16, 2017

\section{REFERENCES}

Ali, M. M., Mageed, A. A. \& Heikal, M., 2007: Importance of aquatic macrophyte for invertebrate diversity in large subtropical reservoir. Limnologica 37, 155-169.

Amoros, C., 1984: Crustaces cladoceres. Bulletin Mensuel de la Société Linnéenne de Lyon 3/4, 1-63.

APHA, 1995: Standard methods for the examination of water and wastewater, 19th edition American Public Health Association, Washington, D.C.

BAscompte, J., 2009: Disentangling the Web of Life. Science 325, 416-419.

BAuernfeind, E. \& Humpesch, U. H., 2001: Die Eintagsfliegen Zentraleuropas (Insecta: Ephemeroptera): Bestimmung und Ökologie, Verlag des Naturhistorischen Museums, Wien.

Bogut, I., Vidaković, J., PAlijan, G. \& ČERBA, D., 2007: Benthic macroinvertebrates associated with four species of macrophytes. Biologia (Bratislava) 62, 600-606.

BRIAND, F. \& CoHEN, J. E., 1984: Community food webs have scale-invariant structure. Nature 307, $264-266$.

Brothers, S. M., Hilt, S., Meyer, S. \& Köhler, J., 2013: Plant community structure determines primary productivity in shallow, eutrophic lakes. Freshwater Biology 58, 2264-2276.

Carlson, R. E., 1977: A trophic state index for lakes. Limnology and Oceanography 22, 361-369.

Cattaneo, A., Galanti, G., Gentinetta, S. \& Romo, S., 1998: Epiphytic algae and macroinvertebrates on submerged and floating-leaved macrophytes in an Italian lake. Freshwater Biology 39, 725-740.

Celewicz-Gołdyn, S., Kuczyńska-Kippen, N., 2017: Ecological value of macrophyte cover in creating habitat for microalgae (diatoms) and zooplankton (rotifers and crustaceans) in small field and forest water bodies. PLoS ONE 12, 5, e0177317.

Chaparro, G., Fontanarrosa, M. S., Cataldo, D. \& O’Farrell, I., 2015: Hydrology driven factors might weaken fish predation effects on zooplankton structure in a vegetated warm temperate floodplain lake. Hydrobiologia 752, 187-202.

Clarke, K. R. \& Warwick, R. M., 2001: Changes in Marine communities: an Approach to Statistical Analysis and Interpretation. PRIMER-E, Plymouth, UK.

Clarke, K. R. \& Gorley, R. N., 2006: PRIMER v6: User Manual/Tutorial. PRIMER-E, Plymouth.

Compte, J., Montenegro, M., Ruhí, A., Gascón, S., SAla, J., Boix, D., 2016: Microhabitat selection and diel patterns of zooplankton in a Mediterranean temporary pond. Hydrobiologia 766, 201-213.

Cremona, F., Planas, D. \& Lucotte, M., 2008: Biomass and composition of macroinvertebrate communities associated with different types of macrophyte architectures and habitats in a large fluvial lake. Fundamental and Applied Limnology - Archiv für Hydrobiologie 171, 119-130. 
Dézerald, O., Leroy, C., Corbara, B., Carrias, J. -F., Pélozuelo, L., Dejean, A. \& Céréghino, R., 2013: Food-Web Structure in Relation to Environmental Gradients and Predator-Prey Ratios in Tank-Bromeliad Ecosystems. PLoS ONE 8: e71735.

DražIna, T., Špoljar, M., Primc, H. \& Habdija, I., 2017: Distribution of rotifers and other meiofauna in the bryophytes and hyporheic zone of a karst hydrosystem - an example of a nested community. Marine and Freshwater Research 68, 43-52.

Duggan, I. C., 2001: The ecology of periphytic rotifers. Hydrobiologia 446/447, 139-148.

Duggan, I. C., Green, J. D., Thompson, K. \& Shiel, R. J., 2001: The influence of macrophytes on the spatial distribution of littoral rotifers. Freshwater Biology 46, 777-786.

Dumont, H. J., van de Velde, I. \& Dumont, S., 1975: The dry weight in a selection of Cladocera, Copepoda and Rotifera from the plankton, periphyton and benthos of continental waters. Oecologia 19, 75-92.

Dunne, J. A., Williams, R. J. \& Martinez, N. D., 2002: Network structure and biodiversity loss in food webs: robustness increases with connectance. Ecology Letters 5, 558-567.

Dunne, J. A., Williams, R. J., Martinez, N. D., Wood, R. A. \& Erwin, D. H., 2008: Compilation and Network Analyses of Cambrian Food Webs. PLoS Biology 6, e102.

Einsle, U., 1993: Crustacea: Copepoda: Calanoida und Cyclopoida. In: Schwoerbel J. \& Zwick P. (Eds). Süsswasserfauna von Mitteleuropa, Gustav Fischer Verlag, Berlin.

Estlander, S., Nurminen, L., Olin, M., Vinni, M. \& Horppila, J., 2009: Seasonal fluctuations in macrophyte cover and water transparency of four brown-water lakes: implications for crustacean zooplankton in littoral and pelagic habitats. Hydrobiologia 620, 109-120.

Foissner, W. \& Berger, H., 1996: A user-friendly guide to the ciliates (Protozoa, Ciliophora) commonly used by hydrobiologists as bioindicators in rivers, lakes, and waste waters, with notes on their ecology. Freshwater Biology 35, 375-482.

Fontaneto, D., Barraclough, T. G., Chen, K., Ricci, C. \& Herniou, E. A., 2008: Molecular evidence for broad-scale distributions in bdelloid rotifers: everything is not everywhere but most things are very widespread. Molecular Ecology 17, 3136-3146.

France, R. L., 2012: Omnivory, vertical food-web structure and system productivity: stable isotope analysis of freshwater planktonic food webs. Freshwater Biology 57, 787-794.

Gilbert, D., Amblard, C., Bourdier, G. \& Francez, A. J., 1998: Short term effect of nitrogen enrichment on the microbial communities of a peatland. Hydrobiologia 373/374, 111-119.

GLÖER, P., 2002: Die Süsswassergastropoden Nord-und Mitteleuropas. Bestimmungsschlüssel, Lebensweise, Verbreitung, ConchBooks, Hackenheim.

Gonzalez Sagrario, M. A., Balseiro, E., Ituarte, R. \& Spivak, E., 2009: Macrophytes as refuge or risky area for zooplankton: a balance set by littoral predacious macroinvertebrates. Freshwater Biology 54, 1042-1053.

Habdija, I., Lajtner, J. \& Belinić, I., 1995: The contribution of gastropod biomass in macrobenthic communities of a karstic river. Internationale Revue der gesamten Hydrobiologie 80, 103-110.

Hampton, S. E. \& Gilbert, J. J., 2001: Observations of insect predation on rotifers. Hydrobiologia 446/447, 115-121.

Hanson, M. A., Buelt, C. A., Zimmer, K. D., Herwig, B. R., Bowe, S. \& Maurer, K., 2015: Co-correspondence among aquatic invertebrates, fish, and submerged aquatic plants in shallow lakes. Freshwater Science 34, 953-964.

Hopkins, C. L., 1961:A Key to the Water Mites (Hydracarina) of the Flatford Area. Field Studies Council 1, 45-49.

KNoz, J., 1965: To identification of Czechoslovakian black-flies (Diptera, Simuliidae). Folia facultatis scientiarum naturalium Universitatis Purkynianae Brunensis 6, 1-52.

Kornijów, R. \& Kairesalo, T., 1994: A simple apparatus for sampling epiphytic communities associates with emergent macrophytes. Hydrobiologia 294, 141-143.

Kovačević, G., Želježić, D., Horvatin, K. \& Kalafatić, M., 2007: Morphological features and comet assay of green and brown hydra treated with aluminium. Symbiosis 44, 145-152.

KuCZyńska-Kippen, N., 2003: The distribution of rotifers (Rotifera) within a single Myriophyllum bed. Hydrobiologia 506-509, 327-331.

KuCZYŃSKA-KipPEN, N. M. \& NAgENGAst, B., 2006: The influence of the spatial structure of hydromacrophytes and differentiating habitat on the structure of rotifer and cladoceran communities. Hydrobiologia 559, 203-212. 
Kuczyńska-Kippen, N. M. \& Wiśniewska, M., 2011: Environmental Predictors of Rotifer Community Structure in Two Types of Small Water Bodies. International Review of Hydrobiology 96, 397-404.

Liboriussen, L., Jeppesen, E., Bramm, M. E. \& Lassen, M. F., 2005: Periphyton-macroinvertebrate interactions in light and fish manipulated enclosures in a clear and a turbid shallow lake. Aquatic Ecology 39, 23-39.

Malekzadeh-Viayeh, R. \& ŠpolJaR, M., 2012: Structure of rotifer assemblages in shallow waterbodies of semi-arid northwest Iran differing in salinity and vegetation cover. Hydrobiologia 686, 73-89.

Malley, D. F., Lawrence, S. G., MacIver, M. A. \& Findlay, W. J., 1989: Range of variation in estimates of dry weight for planktonic Crustacea and Rotifera from temperate North American lakes. Canadian Technical Report of Fisheries and Aquatic Sciences 1666, 1-49.

Martinez, N. D., 1991: Artifacts or Attributes? Effects of Resolution on the Little Rock Lake Food Web. Ecological Monographs 61, 367-392.

Martinez, N., 1992: Constant connectance in community food webs. American Naturalist 140, 1208-1218.

Martinez, N. D., Hawkins, B. A., Dawah, H. A. \& Feifarek, B. P., 1999: Effects of sampling effort on characterization of food-web structure. Ecology 80, 1044-1055.

Meerhoff, M., Mazzeo, N., Moss, B. \& Rodriguez-Gallego, L., 2003: The structuring role of free-floating versus submerged plants in a subtropical shallow lake. Aquatic Ecology 37, 377-391.

Mersuman, P., Pholpunthin, P., Walsh, E. J., Segers, H. \& Wallace, R. L., 2014: Nestedness in sessile and periphytic rotifer communities: A meta-analysis. International Review of Hydrobiology 99, 1-10.

Moog, O., 2002: Fauna Aquatica Austriaca, Lieferung 2002. Wasserwirtschaftskataster, Bundesministerium für Land- und Forstwirtschaft, Umwelt und Wasserwirtschaft, Wien.

Nilsson, A., 1996: Aquatic Insects of North Europe 1. Apollo Books, Stenstrup.

NiLsson, A., 1997: Aquatic Insects of North Europe 2. Apollo Books, Stenstrup.

Nusch, E. A., 1980: Comparison of different methods for chlorophyll and phaeopigment determination. Archiv fur Hydrobiologie Beihandlung 14, 14-36.

Ogden, C. G. \& Hedley, R. H., 1980: An Atlas of Freshwater Testate Amoebae. Oxford University Press, New York.

Polis, G. A., 1991: Complex trophic interactions in deserts: an empirical critique of food web theory. American Naturalist 138,123-155.

Radoman, P., 1983: Hydrobioidea a superfamiliy of Prosobranchia (Gastropoda), I. Systematics. Serbian academy of sciences and arts, Beograd.

Romo, S., Miracle, M. R., Villena, M. -J., Rueda, J., Ferriol, C. \& Vicente, E., 2004: Mesocosm experiments on nutrient and fish effects on shallow lake food webs in a Mediterranean climate. Freshwater Biology 49, 1593-1607.

Rundle, S. D., Robertson, A. L. \& Schmid-Araya, J., 2002: Freshwater Meiofauna: Biology and Ecology. Backhuys Publishers, Leiden.

SCheffer, M., Hosper, S. H. Meijer, M. L. \& Moss, B., 1993: Alternative equilibria in shallow lakes. Trends in Ecology \& Evolution 8, 275-279.

Schmid-Araya, J. M., Hildrew, A. G., Robertson, A., Schmid, P. E. \& Winterbottom, J., 2002a: The importance of meiofauna in food webs: evidence from an acid stream. Ecology 83, 1271-1285.

Schmid-Araya, J. M., Schmid, P. E., Robertson, A., Winterbottom, J., Gjerløv, H. \& Hildrew, A. G., 2002b: Connectance in stream food webs. Journal of Animal Ecology 71, 1056-1062.

Schriever, T. A. \& Williams, D. D., 2013: Influence of pond hydroperiod, size, and community richness on food-chain length. Freshwater Science 32, 964-975.

Sundermann, A. \& Lohse, S., 2004: Bestimmungsschlüssel für die aquatischen Zweiflügler (Diptera) in An-lehnung an die Operationelle Taxaliste für Fließgewässer in Deutschland. In: HAASE P. \& SUnDERMANNA. (Eds.). Standardisierung der Erfassungs - und Auswertungsmethoden von Makrozoobenthosuntersuchungen in Fließgewässern, Abschlussbericht zum LAWA-Projekt O 4.02.

Šroljar, M., Dražina, T., Habdija, I., Meseljević, M. \& GrČić, Z., 2011: Contrasting zooplankton assemblages in two oxbow lakes with low transparencies and narrow emergent macrophyte belts (Krapina River, Croatia). International Review of Hydrobiology 96, 175-190.

Šroljar M., Dražina T., Šargač J., Kralj Borojević K. \& Žutinić P., 2012a: Submerged macrophytes as a habitat for zooplankton development in two reservoirs of a flow-through system (Papuk Nature Park, Croatia). Annales de Limnologie - International Journal of Limnology 48, 161-175. 
Šroljar, M., Fressl, J., Drazina, T., Meseljevic, M. \& Grcic, Z., 2012b: Epiphytic metazoans on emergent macrophytes in oxbow lakes of the Krapina River, Croatia: differences related to plant species and limnological conditions. Acta Botanica Croatica 71, 125-138.

ŠPolJAR, M., 2013: Microaquatic communities as indicators of environmental changes in lake ecosystems. Journal of Engineering Research 1, 29-42.

Špoljar, M., Tomljanović, T., Dražina, T., Lajtner, J., Štuleec, H., Matulić, D. \& Fressl, J., 2016: Zooplankton structure in two interconnected ponds: similarities and differences. Journal of Fisheries 74, 6-13.

Ter BraAk, C. J. F. \& Šmilauer, P. S., 2002: CANOCO Reference Manual and CanoDraw forWindows User's Guide: Software for Canonical Community Ordination (version 4.5). Microcomputer Power, Ithaca, NY.

Thompson, R. M, Brose, U., Dunne, J. A., Hall, Jr. R. O., Hladyz, S., Kitching, R. L., Martinez, N. D., Rantala, H., Romanuk, T. N., Stouffer, D. B. \& Tylianakis, J. M., 2012: Food webs: reconciling the structure and function of biodiversity. Trends in Ecology and Evolution 27, 689-697.

Timm, T., 2009: A guide to the freshwater Oligochaeta and Polychaeta of Northern and Central Europe. Lauterbornia 66, 1-235.

Voigt, M. \& Koste, W., 1978: Die Rädertiere Mitteleuropas. Gebrüder Borntraeger, Berlin, Stuttgart.

Wallace, R. L., Walsh, E. J., Schröder, T., Rico-Martínez, R. \& Rios-Arana, J. V., 2008: Species composition and distribution of rotifers in Chihuahuan Desert waters of México: is everything everywhere? Verhandlungen des Internationalen Verein Limnologie 30, 73-76.

WARfe, D. M. \& BARMUtA, L. A., 2004: Habitat structural complexity mediates the foraging success of multiple predator species. Oecologia 141, 171-178.

WARFE, D.M. \& BARMUTA, L. A., 2006: Habitat structural complexity mediates food web dynamics in a freshwater macrophyte community. Oecologia 150, 141-154.

WARINGER, J. \& GRAF, W., 1997: Atlas der Österreichischen Köcherfliegenlarven. Facultas Universitätsverlag, Wien.

WARREN, P. H., 1989: Spatial and temporal variation in the structure of a freshwater food web. Oikos 55, 299-311.

Whatley, M. H., van Loon, E. E., van Dam, H., Vonk, A., van der Geest, H. G. \& Admiraal, W., 2014: Macrophyte loss drives decadal change in benthic invertebrates in peatland dranage ditches. Freshwater Biology 59, 114-126.

Williams, R. J., 2010: Network3D Software. Microsoft Research, Cambridge, UK.

Williams, R. J. \& Martinez, N. D., 2008: Success and its limits among structural models of complex food webs. Journal of Animal Ecology 77, 512-519.

Williams, R. J., Berlow, E. L., Dunne, J. A., Barabasi, A. L. \& Martinez, N. D., 2002: Two degrees of separation in complex food webs. Proceedings of the National Academy of Sciences USA 99, 1291312916.

Woodward, G. \& Hildrew, A. G., 2001: Invasion of stream food web by a new top predator. Journal of Animal Ecology 70,273-288.

Yoon, I., Williams, R. J., Levine, E., Yoon, S., Dunne, J. A. \& Martinez, N. D., 2004: Webs on the Web (WoW): 3D visualization of ecological networks on the WWW for collaborative research and education. Proceedings of the IS\&T/SPIE Symposium on Electronic Imaging, Visualization and Data Analysis 5295, 124-132. 


\title{
SAŽETAK
}

\section{"Raspetljavanje" hranidbenih mreža u litoralu plitkih jezera umjerene zone}

\author{
M. Špoljar, J. Lajtner, T. Dražina, R. Malekzadeh-Viayeh, I. Radanović, I. Zrinščak, \\ J. Fressl \& D. Matijašec
}

Litoralna zona plitkih jezera često je pokrivena makrofitskim sastojinama koje predstavljaju staništa bogata izvorima hrane, velike brojnosti, biomase i raznolikosti beskralježnjaka i riba. Općenito, makrofitske sastojine smatrane su skloništima od predatora, a u biotičkim interakcijama najčešće je razmatran odnos predator-plijen na primjeru riba i zooplanktona. Razjašnjenje interakcija u hranidbenoj mreži omogućuje bolje razumijevanje funkcioniranja ekosustava te indikaciju antropogenih učinaka koji često uzrokuju promjene uvjeta okoliša i narušavanje hranidbene mreže kopnenih i vodenih ekosustava. Trofičke interakcije mikrofaune (epifitona, zooplanktona) i makrozoobentosa slabo su proučavane u priobalnim (litoralnim) zonama plitkih vodenih tijela. Cilj ovog rada je usporediti interakcije beskralježnjaka i izvora hrane, uključujući epifiton, zooplankton i makrozoobentos u litoralnim zonama različite heterogenosti staništa triju plitkih jezera umjerenog pojasa. Za dobivanje podataka o interakcijama abiotičkih i biotičkih čimbenika korištene su metode multivarijantne analize i primijenjen je program modeliranja hranidbene mreže. Najveća raznolikost (127 svojti) zabilježena je u litoralnoj zoni rukavca sa submerznim sastojinama zbog velike heterogenosti staništa vrste Ceratophyllum demersum, a gotovo dvostruko manje u plitkim mrtvicama čija je litoralna zona pokrivena sastojinama plutajućih makrofita vrste Nuphar lutea. Submerzne i strukturno složene makrofitske sastojine vrste Ceratophyllum demersum naseljavali su u većoj brojnosti rašljoticalci, a također je u njima zbilježena veća raznolikost i biomasa epifitskih Protozoa i beskralježnjaka u usporedbi sa sastojinama plutajuće vrste Nuphar lutea. Analiza funkcioniranja ekosustava ukazivala je na to da je $\mathrm{u}$ heterogenim makrofitskim sastojinama povećana biomasa makrozoobentoskih predatora i izraženija je njihova predacija nad planktonskim rakovima. Hranidbene mreže bile su složenije u heterogenim staništima, a epifiton i zooplankton imali su važan udio u hranidbenim resursima unutar hranidbene mreže beskralježnjaka. Modeliranje hranidbenih mreža inidicira veću ranjivost zooplanktona i epifitona na predaciju beskralježnjaka u kompleksnijim, submerznim, makrofitskim sastojinama u odnosu na sastojine plutajućih makrofita. Time su zooplankton i epifiton obilježeni kao važne karike u hranidbenim mrežama plitkih jezera. Velika heterogenost litoralne zone ujedno predstavlja ne samo kratkotrajni zaklon od predatora, već nasuprot, stalnu izloženost predaciji. Integrirani pristup s aspekta ekologije biocenoza, ekosustava i hranidbenih mreža u objašnjenju složenih trofičkih interakcija u litoralnim zonama potvrdili su povećanje raznolikosti i kompleksnosti funkcioniranja hranidbenih mreža sa strukturalnom heterogenošću mikrostaništa.

Appendix. Name, distribution, size categories and life style of the taxa, and the abbreviations connected with 3D food web models. a: adult; Ie - epiphytic protozoans, IIe - epiphytic metazoans, IIp - zooplankton, IIIb - benthic macroinvertebrates, S - Sutla backwater; Sk - Skrcev kut oxbow; Z - Zajarki gravel pit

\begin{tabular}{|c|c|c|c|c|c|}
\hline \multirow{2}{*}{ Species } & \multicolumn{3}{|c|}{ Study site } & \multirow{2}{*}{ Abbreviation } & \multirow{2}{*}{ Size + Life style } \\
\hline & $\mathrm{S}$ & Sk & Z & & \\
\hline \multicolumn{6}{|l|}{ GYMNAMOEBAE } \\
\hline Amoeba proteus (Pallas, 1766) Leidy, 1878 & $*$ & & & Sarc & Ie \\
\hline Thecamoeba striata (Penard, 1890) & $*$ & & $*$ & Sarc & Ie \\
\hline Vampyrella lateritia (Fresenius, 1856) Leidy, 1879 & & $*$ & & Sarc & Ie \\
\hline \multicolumn{6}{|l|}{ TESTACEA } \\
\hline Arcella discoides Ehrenberg, 1843 & $*$ & $*$ & $*$ & Sarc & Ie \\
\hline
\end{tabular}




\begin{tabular}{|c|c|c|c|c|c|}
\hline \multirow{2}{*}{ Species } & \multicolumn{3}{|c|}{ Study site } & \multirow{2}{*}{ Abbreviation } & \multirow{2}{*}{ Size + Life style } \\
\hline & $\mathrm{S}$ & Sk & $\mathrm{Z}$ & & \\
\hline Centropyxis aculeata (Ehrenberg, 1838) & $*$ & $*$ & $*$ & Sarc & Ie \\
\hline Difflugia oviformis Cash \& Hopkinson, 1909 & $*$ & & & Sarc & Ie \\
\hline Pseudochlamys arcelloides Penard 1904 & & $*$ & & Sarc & $\mathrm{Ie}$ \\
\hline \multicolumn{6}{|l|}{ HELIOZOA } \\
\hline Actinophrys sol Ehrenberg, 1830 & & & $*$ & Sarc & Ie \\
\hline \multicolumn{6}{|l|}{ CILIOPHORA } \\
\hline Amphileptus sp. & & & $*$ & Cili & $\mathrm{Ie}$ \\
\hline Aspidisca costata (Dujardin, 1841) Stein, 1859 & & $*$ & $*$ & Cili & Ie \\
\hline Aspidisca lynceus Müller, 1773 & & $*$ & & Cili & Ie \\
\hline Carchesium polypinum Linnaeus, 1758 & & $*$ & & Cili & Ie \\
\hline Chilodonella uncinata (Ehrenberg, 1838) Strand, 1928 & & $*$ & $*$ & Cili & Ie \\
\hline Cinetochilum margaritaceum Perty, 1852 & $*$ & $*$ & $*$ & Cili & Ie \\
\hline Coleps hirtus (Müller, 1786) & $*$ & $*$ & & Cili & $\mathrm{Ie}$ \\
\hline Cyclidium sp. & $*$ & $*$ & $*$ & Cili & Ie \\
\hline \begin{tabular}{|l} 
Didinium $\mathrm{sp}$. \\
\end{tabular} & & $*$ & & Didi, Cili & Ie \\
\hline Epistylis sp. & $*$ & & & Cili & Ie \\
\hline Euplotes charon (Müller, 1786) Ehrenberg, 1830 & & $*$ & & Cili & Ie \\
\hline Euplotes patella (Müller, 1773) & $*$ & $*$ & & Cili & Ie \\
\hline Glaucoma scintillans Ehrenberg, 1830 & & $*$ & & Cili & Ie \\
\hline Halteria cirrifera Kahl, 1932 & & $*$ & & Cili & Ie \\
\hline Halteria grandinella (Müller, 1773) Dujardin, 1840 & & & $*$ & Cili & Ie \\
\hline Holosticha pulaster (Müller, 1773) & $*$ & $*$ & & Cili & Ie \\
\hline \begin{tabular}{|l} 
Litonotus lamella Schewiakoff, 1896 \\
\end{tabular} & $*$ & $*$ & $*$ & Lito, Cili & Ie \\
\hline Microthorax pusillus Engelmann, 1862 & $*$ & & $*$ & Cili & Ie \\
\hline Nassula ornata Ehrenberg, 1833 & $*$ & $*$ & & Cili & $\mathrm{Ie}$ \\
\hline Opercularia articulata Goldfuss, 1820 & & $*$ & & Cili & Ie \\
\hline Oxytrichidae & $*$ & $*$ & $*$ & Cili & Ie \\
\hline Paramecium bursaria (Ehrenberg, 1831) Focker, 1836 & $*$ & $*$ & & Cili & Ie \\
\hline Podophrya sp. & & $*$ & & Cili & Ie \\
\hline Stentor $\mathrm{sp}$. & $*$ & & & Cili & Ie \\
\hline Tetrahymena pyriformis Ehrenberg, 1830 & $*$ & $*$ & & Cili & Ie \\
\hline Tokophrya lemnarum (Stein, 1859) & & $*$ & & Cili & Ie \\
\hline Uronema nigricans (O.F. Müller, 1786) & $*$ & & * & Cili & Ie \\
\hline Urostyla grandis Ehrenberg, 1830 & $*$ & $*$ & & Cili & Ie \\
\hline Vaginicola sp. & $*$ & $*$ & & Cili & Ie \\
\hline Vorticella campanula Ehrenberg, 1831 & $*$ & $*$ & & Cili & Ie \\
\hline Vorticella microstoma Ehrenberg, 1830 & $*$ & & & Cili & Ie \\
\hline Vorticella monilata Tatem, 1870 & & $*$ & & Cili & Ie \\
\hline Vorticella similis Stokes, 1887 & $*$ & $*$ & & Cili & Ie \\
\hline \multicolumn{6}{|l|}{ HYDROZOA } \\
\hline Hydra viridissima Pallas, 1766 & $*$ & & & Hvir & IIe \\
\hline \multicolumn{6}{|l|}{ TRICLADIDA } \\
\hline Dugesia tigrina Girard, 1850 & $*$ & $*$ & & Tric & IIIb \\
\hline \multicolumn{6}{|l|}{ ROTIFERA } \\
\hline Ascomorpha ovalis (Bergendahl, 1892) & $*$ & $*$ & * & Asco & IIp \\
\hline Asplanchna priodonta Gosse, 1850 & $*$ & $*$ & & Aspl & IIp \\
\hline Bdelloidea & $*$ & $*$ & * & Bdel & IIe \\
\hline
\end{tabular}




\begin{tabular}{|c|c|c|c|c|c|}
\hline \multirow{2}{*}{ Species } & \multicolumn{3}{|c|}{ Study site } & \multirow{2}{*}{ Abbreviation } & \multirow{2}{*}{ Size + Life style } \\
\hline & $\mathrm{S}$ & Sk & $\mathrm{Z}$ & & \\
\hline Brachionus angularis Gosse, 1851 & $*$ & $*$ & & Braa & IIp \\
\hline Brachionus patulus O.F. Müller, 1786 & $*$ & & & Brap & IIp \\
\hline Brachionus quadridentatus Hermann, 1783 & & $*$ & & Braq & IIp \\
\hline Brachionus urceolaris O.F. Müller, 1773 & $*$ & & & Brau & IIp \\
\hline Cephalodella forficula (Ehrenberg, 1838) & $*$ & $*$ & & Ceph & IIe \\
\hline Cephalodella gibba (Ehrenberg, 1832) & $*$ & $*$ & $*$ & Ceph & $\mathrm{IIe}$ \\
\hline Cephalodella spp. & $*$ & $*$ & $*$ & Ceph & IIe \\
\hline Collotheca mutabilis (Hudson, 1885) & $*$ & & & Coll & IIe \\
\hline Colurella obtusa (Gosse, 1886) & $*$ & $*$ & & Colu & IIe \\
\hline Colurella uncinata (O.F. Müller, 1773) & $*$ & $*$ & $*$ & Colu & $\mathrm{IIe}$ \\
\hline Dicranophorus sp. & & $*$ & & Dicr & IIe \\
\hline Epiphanes senta (O.F. Müller, 1773) & * & & & Epip & IIe \\
\hline Euchlanis dilatata (Ehrenberg, 1832) & $*$ & & & Euch & IIe \\
\hline Filinia longiseta (Ehrenberg, 1834) & & $*$ & & Fili & IIp \\
\hline Keratella cochlearis (Gosse, 1851) & $*$ & $*$ & $*$ & Kerc & IIp \\
\hline Keratella quadrata (O.F. Müller 1786) & $*$ & & & Kerq & IIp \\
\hline Keratella tecta (Gosse, 1851) & & $*$ & & Kera & IIp \\
\hline Lecane closterocerca (Schmarda, 1859) & $*$ & $*$ & $*$ & Lec & $\mathrm{IIe}$ \\
\hline Lecane cornuta (Müller, 1786) & $*$ & & & Lec & IIe \\
\hline Lecane flexilis (Gosse, 1886) & * & & & Lec & IIe \\
\hline Lecane luna (Müller, 1776) & $*$ & $*$ & $*$ & Lec & IIe \\
\hline Lecane lunaris (Ehrenberg, 1832) & $*$ & $*$ & $*$ & Lec & $\mathrm{IIe}$ \\
\hline Lepadella patella (O.F. Müller, 1786) & $*$ & & & Lep & IIe \\
\hline Lindia sp. & $*$ & & & Lin & $\mathrm{IIe}$ \\
\hline Lophocharis salpina Ehrenberg, 1832 & $*$ & $*$ & & Loph & IIe \\
\hline Monommata sp. & $*$ & & & Mono & IIe \\
\hline Polyarthra spp. & $*$ & $*$ & & Poly & IIe \\
\hline Pompholyx sulcata Hudson, 1885 & $*$ & & & Pomp & IIp \\
\hline Squatinella lamellaris. f. mutica (Ehrenberg, 1832) & $*$ & * & & Squ & IIe \\
\hline Synchaeta pectinata (Ehrenberg, 1832) & $*$ & & & Sync & IIp \\
\hline Taphrocampa sp. & & & $*$ & Taph & IIp \\
\hline Trichocerca similis (Wierzejski, 1893) & $*$ & $*$ & $*$ & Tric & IIp \\
\hline \multicolumn{6}{|l|}{ GASTROTRICHA } \\
\hline Chaetonotus sp. & $*$ & $*$ & $*$ & Chae & IIe \\
\hline \multicolumn{6}{|l|}{ NEMATODA } \\
\hline Nematoda & $*$ & $*$ & $*$ & Nem & IIe \\
\hline \multicolumn{6}{|l|}{ GASTROPODA } \\
\hline Bithynia tentaculata (Linnaeus, 1758) & & & $*$ & Gast & IIIb \\
\hline Ferrissia fragilis (Tryon, 1863) & $*$ & $*$ & & Gast & IIIb \\
\hline Galba truncatula (O.F. Müller, 1774) & $*$ & & $*$ & Gast & IIIb \\
\hline Gyraulus crista (Linnaeus, 1758) & $*$ & & & Gast & IIIb \\
\hline Gyraulus laevis (Alder, 1838) & $*$ & $*$ & & Gast & IIIb \\
\hline Hippeutis complanatus (Linnaeus, 1758) & $*$ & & & Gast & IIIb \\
\hline Lithoglyphus naticoides (C. Pfeiffer 1828) & & & $*$ & Gast & IIIb \\
\hline Lymnaea stagnalis (Linnaeus, 1758) & & $*$ & & Gast & IIIb \\
\hline Physella acuta (Draparnaud, 1805) & $*$ & $*$ & $*$ & Gast & IIIb \\
\hline Radix auricularia (Linnaeus, 1758) & $*$ & & $*$ & Gast & IIIb \\
\hline
\end{tabular}




\begin{tabular}{|c|c|c|c|c|c|}
\hline \multirow{2}{*}{ Species } & \multicolumn{3}{|c|}{ Study site } & \multirow{2}{*}{ Abbreviation } & \multirow{2}{*}{ Size + Life style } \\
\hline & $\mathrm{S}$ & $\mathrm{Sk}$ & Z & & \\
\hline Radix labiata (Rossmässler, 1835) & & & $*$ & Gast & $\mathrm{IIIb}$ \\
\hline Valvata piscinalis (O.F. Müller, 1774) & $*$ & & $*$ & Gast & IIIb \\
\hline \multicolumn{6}{|l|}{ BIVALVIA } \\
\hline Pisidium sp. & $*$ & $*$ & * & Pis & IIIb \\
\hline \multicolumn{6}{|l|}{ OLIGOCHAETA } \\
\hline Eiseniella tetraedra (Savigny 1826) & $*$ & & $*$ & Oli & IIIb \\
\hline Enchytraeidae & $*$ & $*$ & $*$ & Oli & IIIb \\
\hline Lumbricidae & $*$ & $*$ & $*$ & Oli & IIIb \\
\hline Lumbriculidae & $*$ & $*$ & $*$ & Oli & IIIb \\
\hline Naididae & $*$ & $*$ & $*$ & Oli & $\mathrm{IIIb}$ \\
\hline \multicolumn{6}{|l|}{ HIRUDINEA } \\
\hline Helobdella stagnalis Linnaeus, 1758 & $*$ & & & Helo & IIIb \\
\hline \multicolumn{6}{|l|}{ TARDIGRADA } \\
\hline Macrobiotus sp. & $*$ & & & Tard & IIe \\
\hline \multicolumn{6}{|l|}{ HYDRACHNIDIA } \\
\hline Arrenurus (Truncaturus) fontinalis K. Viets, 1920 & $*$ & & * & Hydr & IIIb \\
\hline Arrenurus globator (O.F. Müller, 1776) & $*$ & & & Hydr & IIIb \\
\hline Hydrodroma pilosa Besseling, 1940 & $*$ & & & Hydr & IIIb \\
\hline Limnesia undulata (O.F. Müller, 1776) & $*$ & & & Hydr & $\mathrm{IIIb}$ \\
\hline Limnochares aquatica (Linnaeus, 1758) & $*$ & & & Hydr & IIIb \\
\hline Neumania angulata Sokolow, 1931 & $*$ & & & Hydr & IIIb \\
\hline Piona conglobata (Koch, 1836) & $*$ & $*$ & $*$ & Hydr & IIIb \\
\hline Unionicola figuralis (Koch, 1836) & $*$ & & & Hydr & IIIb \\
\hline \multicolumn{6}{|l|}{ ARANEAE } \\
\hline Argyroneta aquatica (Clerck, 1758) & $*$ & & & Arg & IIIb \\
\hline \multicolumn{6}{|l|}{ CLADOCERA } \\
\hline Bosmina longirostris (O.F. Müller, 1776) & $*$ & $*$ & $*$ & Bos & IIp \\
\hline Daphnia obtusa Kurz, 1874 & $*$ & & $*$ & Dap & IIp \\
\hline Iliocryptus agilis Kurz, 1878 & & $*$ & & Ilio & IIe \\
\hline Iliocryptus sordidus (Liévin, 1848) & $*$ & & & Ilio & IIe \\
\hline Sida crystallina (O.F. Müller, 1776) & & & $*$ & Sid & IIe \\
\hline Simocephalus vetulus (O.F. Müller, 1776) & $*$ & $*$ & $*$ & Sim & IIp \\
\hline \multicolumn{6}{|l|}{ COPEPODA } \\
\hline Macrocyclops albidus $_{1, \mathrm{a}}($ Jurine, 1820) & $*$ & $*$ & $*$ & Mcyc & IIp \\
\hline nauplii & & & & naup & IIp \\
\hline copepodites & & & & cope & IIp \\
\hline \multicolumn{6}{|l|}{ OSTRACODA } \\
\hline Cyclocypris sp. & $*$ & & & Cycl & IIp \\
\hline \multicolumn{6}{|l|}{ ISOPODA } \\
\hline Asellus aquaticus (Linnaeus, 1758) & & & $*$ & Asel & IIIb \\
\hline \multicolumn{6}{|l|}{ EPHEMEROPTERA } \\
\hline Brachycercus harrisella Curtis 1834 & & $*$ & & Brac & IIIb \\
\hline Caenis macrura Stephens 1835 & & & $*$ & Caen & $\mathrm{IIIb}$ \\
\hline Caenis pusilla Navás, 1913 & $*$ & & & Caen & IIIb \\
\hline Caenis rivolorum Eaton, 1884 & & $*$ & & Caen & IIIb \\
\hline Centroptilum luteolum (Müller 1776) & $*$ & & & Cent & IIIb \\
\hline Ephemera danica Müller, 1764 & & & $*$ & Ephe & IIIb \\
\hline
\end{tabular}




\begin{tabular}{|c|c|c|c|c|c|}
\hline \multirow{2}{*}{ Species } & \multicolumn{3}{|c|}{ Study site } & \multirow{2}{*}{ Abbreviation } & \multirow{2}{*}{ Size + Life style } \\
\hline & $\mathrm{S}$ & Sk & $\mathrm{Z}$ & & \\
\hline Leptophlebia vespertina (Linnaeus 1758) & $*$ & & & Lept & IIIb \\
\hline Parameletus sp. & $*$ & & & Par & IIIb \\
\hline Potamanthus luteus (Linnaeus, 1767) & $*$ & & & Pota & IIIb \\
\hline \multicolumn{6}{|l|}{ ODONATA } \\
\hline Coenagrion sp. & $*$ & & & Coen & IIIb \\
\hline Gomphus sp. & $*$ & & & Gomp & IIIb \\
\hline \multicolumn{6}{|l|}{ HETEROPTERA } \\
\hline Gerris buenoi Kirkaldy, 1911 & $*$ & & & Gerr & $\mathrm{IIIb}$ \\
\hline Mesovelia mulsanti White 1879 & $*$ & & & Meso & IIIb \\
\hline Micronecta sp. & $*$ & & $*$ & Micn & IIIb \\
\hline Microvelia reticulata (Burmeister, 1835) & $*$ & & & Micr & IIIb \\
\hline Naucoris maculatus Fabricius, 1782 & * & & & Nauc & IIIb \\
\hline Notonecta glauca Linnaeus, 1758 & $*$ & & & Noto & IIIb \\
\hline Plea minutissima Leach, 1817 & $*$ & & & Plea & IIIb \\
\hline \multicolumn{6}{|l|}{ COLEOPTERA } \\
\hline${\text { Bledius } \mathrm{sp}_{\mathrm{a}}}$ & $*$ & & $*$ & Bled & IIIb \\
\hline Deronectes latus a $_{\mathrm{a}}$ Stephens, 1829) & $*$ & & & Dero & $\mathrm{IIIb}$ \\
\hline Gyrinus sp. & & & $*$ & Gyr & IIIb \\
\hline Haliplus fulvus $_{\mathrm{a}}$ (Fabricius 1801) & $*$ & & & Hali & IIIb \\
\hline 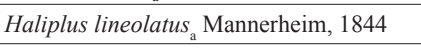 & $*$ & & & Hali & $\mathrm{IIIb}$ \\
\hline \multicolumn{6}{|l|}{ DIPTERA } \\
\hline Ablabesmyia sp. & $*$ & & & Abla & IIIb \\
\hline Aedes sp. & $*$ & & & Aed & IIIb \\
\hline Anopheles maculipennis & $*$ & & & Ano & $\mathrm{IIIb}$ \\
\hline Bezzia sp. & $*$ & & $*$ & Bezz & $\mathrm{IIIb}$ \\
\hline Chaoborus sp. & & $*$ & & Chao & $\mathrm{IIIb}$ \\
\hline Chionea sp. & & & $*$ & Chio & IIIb \\
\hline Chrysops sp. & & & $*$ & Chry & IIIb \\
\hline Cricotopus sp. & $*$ & & & Cric & IIIb \\
\hline Dicrotendipes sp. & $*$ & & & Dic & IIIb \\
\hline Megaselia kovaci ${ }_{\mathrm{p}}$ Disney, 1991 pupae & $*$ & & & & IIIb \\
\hline Oxycera pulchella Meigen, 1822 & $*$ & & & Oxyc & $\mathrm{IIIb}$ \\
\hline Parakiefferiella sp. & $*$ & & & Par & IIIb \\
\hline Polypedilum sp. & $*$ & & & Poly & IIIb \\
\hline Procladius $\mathrm{sp}$. & $*$ & & & Proc & IIIb \\
\hline Psychoda sp. & & & $*$ & Psyc & IIIb \\
\hline Stilobezzia sp. & $*$ & & & Stbz & $\mathrm{IIIb}$ \\
\hline Tanytarsus sp. & $*$ & $*$ & & Tany & $\mathrm{IIIb}$ \\
\hline Thienemannimyia sp. & $*$ & & $*$ & Thie & $\mathrm{IIIb}$ \\
\hline \multicolumn{6}{|l|}{ TRICHOPTERA } \\
\hline Orthotrichia sp. & $*$ & & & Orth & IIIb \\
\hline Polycentropus sp. & $*$ & & $*$ & Pct & IIIb \\
\hline Psychomyia sp. & $*$ & & & Psy & IIIb \\
\hline Rhyacophila sp. & & $*$ & & Rhya & IIIb \\
\hline \multicolumn{6}{|l|}{ LEPIDOPTERA } \\
\hline Parapoynx stratiotatum (Linnaeus, 1758) & $*$ & & & Pars & IIIb \\
\hline
\end{tabular}

